\title{
Molecular detection of Theileria species, Anaplasma species, Candidatus Mycoplasma haemobos, Trypanosoma evansi and first evidence of Theileria sinensis-associated bovine anaemia in crossbred Kedah- Kelantan x Brahman cattle
}

Onyinyechukwu Ada Agina ${ }^{1,2}$, Mohd Rosly Shaari ${ }^{3}$, Nur Mahiza Md Isa', Mokrish Ajat ${ }^{1}$, Mohd Zamri-Saad ${ }^{1}$, Mazlina Mazlan ${ }^{1}$, Azim Salahuddin Muhamad ${ }^{4}$, Afrah Alhana Kassim, Lee Chai Ha ${ }^{5}$, Fairuz Hazwani Rusli',

Darulmuqaamah Masaud ${ }^{1}$ and Hazilawati Hamzah ${ }^{1 *}$ (D)

\begin{abstract}
Background: Serious disease outbreaks in cattle are usually associated with blood pathogens. This study aims to detect blood pathogens namely Theileria species, Anaplasma species, Candidatus Mycoplasma haemobos and Trypanosoma evansi, and determine their phylogenetic relationships and haemato-biochemical abnormalities in naturally infected cattle.

Methods: Molecular analysis was achieved by PCR amplification and sequencing of PCR amplicons of 18SrRNA gene of Theileria species, 16SrRNA genes of Anaplasma and Mycoplasma species, MPSP genes of T. orientalis and T. sinensis, MSP4 gene of A. marginale, 16SrRNA gene of Candidatus Mycoplasma haemobos, and RoTat1.2 VSG gene of Trypanosoma evansi, in sixty-one (61) clinically ill Kedah-Kelantan x Brahman cattle in Pahang, Malaysia.
\end{abstract}

\footnotetext{
* Correspondence: hazilawati@upm.edu.my

${ }^{1}$ Faculty of Veterinary Medicine, Universiti Putra Malaysia, UPM, 43400 Serdang, Selangor, Malaysia

Full list of author information is available at the end of the article
}

C C The Author(s). 2021 Open Access This article is licensed under a Creative Commons Attribution 4.0 International License, which permits use, sharing, adaptation, distribution and reproduction in any medium or format, as long as you give appropriate credit to the original author(s) and the source, provide a link to the Creative Commons licence, and indicate if changes were made. The images or other third party material in this article are included in the article's Creative Commons licence, unless indicated otherwise in a credit line to the material. If material is not included in the article's Creative Commons licence and your intended use is not permitted by statutory regulation or exceeds the permitted use, you will need to obtain permission directly from the copyright holder. To view a copy of this licence, visit http://creativecommons.org/licenses/by/4.0/. The Creative Commons Public Domain Dedication waiver (http://creativecommons.org/publicdomain/zero/1.0/) applies to the data made available in this article, unless otherwise stated in a credit line to the data. 
Results: A total of 44 (72.13\%) cattle were infected with more than one blood pathogen. Theileria species was the blood pathogen with the highest molecular detection rate $(72.13,95 \% \mathrm{Cl} 59.83-81.81 \%)$. Nucleotide blast analyses of all sequences demonstrated high degree of molecular similarity (98-100\%) in comparison with their respective reference sequences. Analysis of 18SrRNA gene sequences of Theileria species and 16SrRNA gene sequences of Anaplasma species revealed Theileria sinensis and Anaplasma platys respectively as additional species detected in these cattle. MPSP-PCR analysis was conducted for further confirmation of $T$. sinensis. The blood picture of eight infected cattle groups revealed poikilocytosis, anisocytosis, rouleaux formation and degenerative left shift. High mean erythrocyte fragility values were common in infected cattle groups. Anaemia of the macrocytic normochromic type and spherocytes were observed in the T. evansi and Anaplasma platys + Theileria sinensis double species co-infected cattle group. Normocytic normochromic anaemia was observed in the $T$. sinensis infected cattle group. Significant $(p<0.05)$ increases in serum liver and kidney parameters, total protein, globulin, total and unconjugated bilirubin and decreased albumin values were observed in the T. evansi infected cattle when compared to clinically healthy cattle.

Conclusion: We present the first evidence of Theileria sinensis-associated bovine anaemia (TSABA) in Malaysian cattle. Because of the high occurrence of bovine theileriosis and detection of A. platys, there is an urgent need for appropriate preventive and control measures against these blood pathogens.

Keywords: Blood pathogens, PCR, Cattle, Haemato-biochemistry, Erythrocyte osmotic fragility, Phylogeny

\section{Background}

Theileriosis, anaplasmosis, hemoplasmosis and trypanosomosis are economically important vector-borne diseases of cattle, usually characterised by high morbidity and high mortality in clinical cases [1-5]. These diseases are ranked among the most common causes of economic losses in livestock industry [2]. The Anaplasma, Theileria, Mycoplasma (Haemotropic Mycoplasmas) and Trypanosoma species are the commonly found blood pathogens in Malaysian cattle $[1,6]$ and are transmitted by Ixodid ticks such as Hemaphysalis sp., Rhipicephalus $s p$., and Amblyomma sp. [7]. These blood pathogens have constrained cattle production in Malaysia [1], and affected cattle become severely anaemic, anorexic, feverish, jaundice, unthrifty and dehydrated. In addition, hyperproteinemia, leukopenia and thrombocytopenia have been reported in blood pathogen infected animals. Affected animals may abort or die in severe cases $[8,9]$. A consistent feature of these diseases is that, following recovery from primary infection, affected cattle become asymptomatic and persistent carriers, acting as reservoirs of infection to susceptible or immunocompromised animals $[9,10]$. These asymptomatic carriers show low levels of parasitaemia which is usually difficult to detect by microscopy [11]. Therefore, molecular techniques are usually more accurate in diagnosing subclinical or chronic infections [12, 13]. Trypanosomosis (Surra) is a mechanically transmitted disease of cattle and horses. It is of high endemicity in tropical and sub-tropical parts of the world. The causative agent is Trypanosoma evansi, an extracellular flagellated blood protozoan and the most widely distributed pathogenic trypanosome [14]. The acute form of the disease is characterised by anaemia with high mortality in susceptible animals, generalised loss of body condition, reduced fertility, poor immune response and death in protracted cases [15].

Bovine haemoplasmosis is caused by the haemotropic mycoplasmas namely Mycoplasma wenyonii and Candidatus Mycoplasma haemobos which are gram-negative, cell wall-less epierythrocytic bacteria found attached onto the surface of erythrocytes [16]. In affected herd, the bacteria cause severe anaemia, oedema and infertility $[17,18]$. Anaplasmosis is caused by Anaplasma marginale and $A$. centrale in cattle $[19,20]$ and $A$. platys in dogs, ruminants and humans [21-23]. Intraerythrocytic inclusion bodies are found in blood smears of cattle infected with Anaplasma species. Also, anaplasmosis is mainly characterised by anaemia of the haemolytic type which may or may not be immune-mediated [24]. Anorexia, icterus, weight loss, decreased milk production, and dehydration are evident in susceptible animals [9]. Bovine theileriosis affects domesticated cattle and is associated with significant reduction in cattle productivity [25]. Theileriosis caused by T. annulata (tropical theileriosis) and T. parva (East coast fever) are of high pathogenicity [26], compared to the benign bovine theileriosis caused by the $T$. orientalis/buffeli/sergenti complex [26]. Oriental theileriosis is associated with low pathogenicity because $T$. orientalis schizont infected blood cells are not commonly observed in peripheral blood circulation in ruminants [27]. Recently, serious outbreaks of oriental theileriosis caused by the $T$. orientalis Ikeda type have been reported in the Asia-Pacific region [28, 29]. East coast fever caused by $T$. parva predominately affects catthe in Africa, but T. annulata has a world-wide distribution [2]. T. parva and T. annulata are the most 
pathogenic protozoa in animals [30], and their schizonts cause incomplete neoplastic transformation, proliferation and immortalisation of $\mathrm{T}$ cells [31]. Theileria sinensis which is a phylogenetically closely related member of T. orientalis complex is known to be one of the major causes of bovine theileriosis in China [32] and has been recently reported as one of the causes of benign bovine theileriosis in Malaysia [26]. It is of low pathogenicity in affected cattle [13].

In ruminants, haematology and serum biochemical analyses are relevant for detecting haematological disorders and pathological changes in vital organs of the body [33]. Results from such tests (complete blood count, liver and kidney function tests) provide valuable information that enables the clinician to arrive at a diagnosis, assess the efficacy of instituted therapy and monitor the disease process (static, progressing or regressing) [33]. An increase or decrease in haematology and serum biochemistry parameters have been reported in blood pathogen infections. The extent to which the haematology and serum biochemistry parameters are altered depends on several factors such as host immunity, age, infectious dose, virulence and infecting blood pathogen species [34]. Anaplasma and Theileria species infect and multiply inside the red blood cells, and during this intraerythrocytic stage, intravascular or immune-mediated haemolysis can occur leading to anaemia [35]. Anaemia is a common finding in vector-borne diseases, and it is usually as a result of intravascular or extravascular destruction of the red cells. Anaemia of the macrocytic normochromic to macrocytic hypochromic (trypanosomosis) or normocytic normochromic (anaplasmosis and theileriosis) type is usually evident in affected animals [36]. Immune-mediated haemolytic anaemia has been reported in bovine anaplasmosis and theileriosis [24]. Osmotic erythrocyte fragility test is widely used as an aid to diagnosis of certain haematological disorders such as intravascular haemolytic anaemia, autoimmune diseases, spherocytosis, elliptocytosis and stomatocytosis $[37,38]$. Evaluation of the membrane stability of erythrocytes under hypoosmotic stress is performed by lysis of erythrocytes in decreasing concentrations of hypotonic buffered saline solutions [39]. Erythrocyte osmotic fragility test is widely used as an aid to diagnosis of certain haematological disorders that involves alteration in erythrocyte membrane such as intravascular haemolytic anaemia, autoimmune diseases, hereditary spherocytosis, elliptocytosis and stomatocytosis [40]. Abnormalities in erythrocyte membrane also occur in bovine blood pathogen diseases such as babesiosis, trypanosomosis and anaplasmosis [8, 37, 41, 42]. Other factors such as nutritional status, hormonal imbalance, drugs and chemical intoxications, age, transportation stress could also increase the fragility of erythrocytes [43-45].
Diseases caused by blood pathogens have negative impact on the livestock industry in Malaysia. Therefore, it is essential to improve detection and surveillance of these blood pathogens [46]. Use of light microscopy for identification in stain blood smears are usually ineffective for differentiation of the species and detection of asymptomatic, presymptomatic and carrier animals with low parasitaemia. The use of molecular (PCR) based detection method has enabled better detection of these blood pathogens with high sensitivity and specificity [26, 30]. A need to determine the phylogenetic relationships and to have a better molecular taxonomic understanding of the infections caused by various species of commonly occurring blood pathogens in Malaysian cattle is required. Therefore, this present study provides the molecular characteristics of Theileria species, Trypanosoma evansi, Candidatus M. haemobos and Anaplasma species in Muadzam, Pahang Malaysia and ascertained the haemato-biochemical abnormalities and erythrocyte osmotic fragility in clinically ill crossbred Kedah-Kelantan $x$ Brahman cattle infected with these blood pathogens.

\section{Methods}

\section{Ethical statement}

This study was conducted according to the guidelines of the Animal Care and Use Committee, Universiti Putra Malaysia, Animal Welfare Act (2014) AUP No. UPM/ IACUC/AUP-R008/2020.

\section{Study population and blood sampling}

Ten (10) $\mathrm{mL}$ each were obtained by coccygeal venipuncture from randomly selected 61 clinically ill and 17 clinically healthy Kedah-Kelantan $\mathrm{x}$ Brahman cattle of varying ages (1-11 years old) and sex (male and female) from a beef farm in Muadzam Pahang, Malaysia. The animals were reared in an oil palm plantation, and grazed forages under palm oil plantation with some mineral supplementation. The clinically ill cattle were physically examined, and clinical signs were noted before blood samples were obtained. The seventeen (17) clinically healthy cattle were selected based on absence of blood pathogens confirmed by throrough screening for blood pathogens by microscopic and molecular methods, absence of clinical signs of the disease, absence of tick infestation and moderate body condition. The blood samples were placed in a pre-labelled K2 EDTA vacutainer tubes for haematological analyses, heparin vacutainers for erythrocyte osmotic fragility test and plain vacutainers to harvest sera for biochemical analyses. The samples were then transported in an ice box to the Haematology and Clinical Biochemistry Laboratory, Faculty of Veterinary Medicine, Universiti Putra Malaysia. Whole blood samples for PCR were stored at $-80^{\circ} \mathrm{C}$ prior to DNA extraction. Extracted genomic DNA was 
subjected to genera and species-specific PCR test for detection of these blood pathogens.

\section{Microscopic examination of stained thin-blood smears}

Giemsa stained thin-blood smears were examined for possible detection and identification of blood pathogens with the aid of a light microscope (Nikon Eclipse 80i, Tokyo Japan).

\section{Determination of haemato-biochemical parameters}

Haematology parameters such as haemoglobin concentration, red blood cell, total white blood cell and platelet counts were performed by an automated haemoanalysers (Advia 2120i Siemens-Healthineers, Malvern, USA). Packed cell volume was performed using the microhaematocrit technique with the aid of haematocrit centrifuge (Haematokrit 20, Hettich Zentrifugen, Tuttlingen, Germany), and Hawksley micro-haematocrit reader (Hawksley, England). Sera were harvested using a portable table centrifuge (EBA 20 Hettich Zentrifugen, Tuttlingen, Germany). Serum sodium, potassium and chloride were determined using Siemens Xpand Plus Chemistry Analyser (Siemens Healthineers, Malvern, USA). Serum aspartate aminotransferase (AST), alkaline phosphatase (ALP), gamma glutamyltransferase (GGT), total bilirubin (TB), conjugated bilirubin (CB), inorganic phosphate (IP), urea, creatinine total protein (TP) and albumin (ALB), were done using BiOLis 24i Premium Chemistry Analyser (DiaSystem Scandinavia AB, Sweden). Globulin was calculated by subtracting the albumin value from total protein value. Albumin to globulin ratio was calculated by dividing the albumin value with the globulin value. Plasma protein was determined using a hand-held refractometer (Atago, USA) while icteric index was determined by comparing the colour of test plasma sample with a set of colour standards.

\section{Erythrocyte osmotic fragility test}

Erythrocyte osmotic fragility (EOF) was determined by subjecting erythrocytes to varying concentrations of buffered saline solutions with slight modification [38, 47]. Briefly, $5 \mathrm{~mL}$ of different buffered saline concentrations of $\mathrm{pH} 7.4$ ranging from 0.1 to $0.9 \%$ were pipetted into 5 test tubes arranged serially in a test tube rack. A set of 5 test tubes was used to analyse each sample. Whole blood $(20 \mu \mathrm{L})$ was pipetted into each test tube and mixed thoroughly by inverting the test tubes several times to mix the content. The mixed blood was incubated at room temperature for $20 \mathrm{~min}$. The content was mixed again before spinning at $1500 \mathrm{x}$ g for $15 \mathrm{~min}$. The supernatant was transferred into cuvette and read at an absorbance of $540 \mathrm{~nm}$ using a spectrophotometer (Tecan Biochem, USA). The percentage haemolysis was calculated with the following formula:
Haemolysis(\%) : (Optical density of test/Optical density of distille

The EOF curve was obtained by plotting the haemolysis percentage against the different saline concentration. The result of the EOF is expressed as the saline concentration that caused 50\% haemolysis, which is the mean cell fragility (MCF).

\section{Genomic DNA extraction}

Genomic DNA was extracted from whole blood stored at $-80^{\circ} \mathrm{C}$ using the DNeasy ${ }^{\circ}$ Blood and Tissue kit (Qiagen, Hilden Germany) according to the manufacturers' protocol. The eluted DNA was stored at $-20^{\circ} \mathrm{C}$ until use. DNA concentration and purity were measured with a Nanodrop spectrophotometer (Tecan Infinite $\mathrm{M} 200^{\circ}$, Austria). DNA samples with $A_{260} / A_{280}$ ratios between 1.7-2.2 were further analysed.

\section{Molecular identification by PCR}

Polymerase chain reaction assay was done to amplify the partial gene fragments of Anaplasma, Theileria and Mycoplasma species using genus and species-specific primer sets (Table 1). Detection of RoTat 1.2 VSG gene for $T$. evansi was done using species-specific primer set (Table 1). Thermocyclic conditions and primers for Anaplasma, Theileria and Mycoplasma species were as specified by Parola et al. [48]; Sogin et al. [49]; and Su et al. [50] respectively (Table 1). All samples positive for $18 \mathrm{~S}$ ribosomal RNA gene of Theileria species and $16 \mathrm{~S}$ ribosomal RNA genes of Anaplasma and Mycoplasma species were further amplified by conventional PCR using species-specific primer sets (Table 1), targeting major piroplasm surface protein (MPSP) genes of $T$. orientalis and $T$. sinensis, major surface protein 4 (MSP4) gene for A. marginale and $16 \mathrm{~S}$ ribosomal RNA of C. Mycoplasma haemobos. Thermocyclic conditions and primers for $A$. marginale, T. orientalis, T. sinensis, T. evansi and C. $M$. haemobos were as specified by Shkap et al. [51], Ota et al. [52], Liu et al. [53], Urakawa et al. [54] and Su et al. [50] respectively (Table 1 ). Each PCR run was performed in a final volume of $25 \mu \mathrm{L}$ reaction in $0.2 \mathrm{~mL}$ PCR reaction tubes, comprised of $0.3 \mu \mathrm{L}$ of $10 \mathrm{mM}$ dNTP mix (dATP, dCTP, dGTP, dTTP), $1 \mu \mathrm{L}$ of $10 \mu \mathrm{M}$ of each primer, $5 \mu \mathrm{L}$ of $5 \mathrm{X}$ Green $\mathrm{GoTaq}^{\circ}$ flexi buffer (Promega Madison WI, USA), $5 \mu \mathrm{L}$ of $25 \mathrm{mM} \mathrm{MgCl}_{2}$, $0.3 \mu \mathrm{L}$ of $5 \mathrm{U} \mathrm{GoTaq}^{\circ} \mathrm{G} 2$ flexi DNA polymerase (Promega Madison WI, USA), $8.4 \mu \mathrm{L}$ of water for molecular biology (Millipore corporation, Billerica MA, USA) and $100 \mathrm{ng}$ of template DNA. The positive control DNA used in the PCR run consisted of a field strain confirmed by PCR and sequencing of the amplicon, and was obtained from the Veterinary Parasitology Laboratory, Universiti Putra Malaysia. Water for molecular biology (Millipore corporation, Billerica MA, USA) was used as 
Table 1 Genus and species-specific primers, thermocyclic conditions and amplicon size of the various genes used for the detection and amplification of cattle blood pathogens. Thermocyclic conditions include initial denaturing (ID), denaturing (D), annealing (A), extension (E), and final extension (FE)

\begin{tabular}{|c|c|c|c|c|c|}
\hline Blood Pathogens & Gene & $\begin{array}{l}\text { Primer Sequences }\left(5^{\prime}-3^{\prime}\right) \text { Forward }(F) \text { and } \\
\text { Reverse (R) }\end{array}$ & $\begin{array}{l}\text { Thermocyclic } \\
\text { conditions }\end{array}$ & $\begin{array}{l}\text { Base pair } \\
\text { (bp) }\end{array}$ & References \\
\hline Anaplasma species & 16SrRNA & $\begin{array}{l}\text { EHR16SD - GGTACCYACAGAAGAAGTCC } \\
\text { EHR 16SR -TAGCACTCATCGTTACAGC }\end{array}$ & $\begin{array}{l}\text { ID: } 95^{\circ} \mathrm{C} / 5 \mathrm{mins} \\
\text { D: } 95^{\circ} \mathrm{C} / 30 \mathrm{~s} \\
\text { A: } 55^{\circ} \mathrm{C} / 30 \mathrm{~s} \\
\text { E: } 72^{\circ} \mathrm{C} / 90 \mathrm{~s} \\
\text { No of cycles: } 40 \\
\text { FE: } 72^{\circ} \mathrm{C} / 5 \text { mins }\end{array}$ & 345 & {$[47]$} \\
\hline Theileria species & 18SrRNA & $\begin{array}{l}\text { F-ACCTGGTTGATCCTGCCAG } \\
\text { R-GATCCTTCGCAGGTTCACCTAC }\end{array}$ & $\begin{array}{l}\text { ID: } 94^{\circ} \mathrm{C} / 5 \mathrm{mins} \\
\text { D: } 94^{\circ} \mathrm{C} / 30 \mathrm{~s} \\
\text { A: } 60^{\circ} \mathrm{C} / 30 \mathrm{~s} \\
\text { E: } 72^{\circ} \mathrm{C} / 1 \mathrm{~min} \\
\text { No of cycles: } 40 \\
\text { FE: } 72^{\circ} \mathrm{C} / 5 \text { mins }\end{array}$ & 1750 & {$[48]$} \\
\hline Mycoplasma species & 16SrRNA & $\begin{array}{l}\text { F-GGGAGCAAACAGGATTAGATACCCT } \\
\text { R-TGCACCATCTGTCACTCTGTTAACCTC }\end{array}$ & $\begin{array}{l}\text { ID: } 94^{\circ} \mathrm{C} / 5 \mathrm{mins} \\
\text { D: } 94^{\circ} \mathrm{C} / 30 \mathrm{~s} \\
\text { A: } 55^{\circ} \mathrm{C} / 30 \mathrm{~s} \\
\text { E: } 72^{\circ} \mathrm{C} / 1 \text { min } 50 \text { secs } \\
\text { No of cycles: } 40 \\
\text { FE: } 72^{\circ} \mathrm{C} / 10 \text { mins }\end{array}$ & 280 & [49] \\
\hline Anaplasma marginale & MSP4 & $\begin{array}{l}\text { F- CATCTCCCATGAGTCACGAAGTGGC } \\
\text { R-GCTGAACAGGAATCTTGCTCCAAG }\end{array}$ & $\begin{array}{l}\text { ID: } 95^{\circ} \mathrm{C} / 5 \mathrm{mins} \\
\text { D: } 95^{\circ} \mathrm{C} / 1 \mathrm{~min} \\
\text { A: } 65^{\circ} \mathrm{C} / 2 \mathrm{mins} \\
\text { E: } 72^{\circ} \mathrm{C} / 1 \mathrm{~min} \\
\text { No of cycles: } 40 \\
\text { FE: } 72^{\circ} \mathrm{C} / 10 \mathrm{~min}\end{array}$ & 761 & {$[50]$} \\
\hline Theileria orientalis & MPSP & $\begin{array}{l}\text { F- CTITGCCTAGGATACTTCCT } \\
\text { R- ACGGCAAGTGGTGAGAACT }\end{array}$ & $\begin{array}{l}\text { ID: } 94^{\circ} \mathrm{C} / 4 \mathrm{mins} \\
\text { D: } 94^{\circ} \mathrm{C} / 1 \mathrm{~min} \\
\text { A: } 63^{\circ} \mathrm{C} / 1 \mathrm{~min} \\
\text { E: } 72^{\circ} \mathrm{C} / 1 \mathrm{~min} \\
\text { No of cycles: } 40 \\
\text { FE: } 72^{\circ} \mathrm{C} / 7 \text { mins }\end{array}$ & 776 & [51] \\
\hline Theileria sinensis & MPSP & $\begin{array}{l}\text { Tsin F- CACTGCTATGTTGTCCAAGAGATATT } \\
\text { Tsin R-AATGCGCCTAAAGATAGTAGAAAAC }\end{array}$ & $\begin{array}{l}\text { ID: } 94^{\circ} \mathrm{C} / 3 \mathrm{mins} \\
\text { D: } 94^{\circ} \mathrm{C} / 1 \mathrm{~min} \\
\text { A: } 56^{\circ} \mathrm{C} / 1 \mathrm{~min} \\
\text { E: } 72^{\circ} \mathrm{C} / 1 \mathrm{~min} \\
\text { No of cycles: } 40 \\
\text { FE: } 72^{\circ} \mathrm{C} / 7 \mathrm{mins}\end{array}$ & 887 & [52] \\
\hline Trypanosoma evansi & $\begin{array}{l}\text { RoTaT } 1.2 \\
\text { VSG }\end{array}$ & $\begin{array}{l}\text { F-GCG GGG TGT TTA AAG CAA TA } \\
\text { R-ATT AGT GCT GCG TGT GTT CG }\end{array}$ & $\begin{array}{l}\text { ID: } 94^{\circ} \mathrm{C} / 4 \mathrm{mins} \\
\text { D: } 94^{\circ} \mathrm{C} / 1 \mathrm{~min} \\
\text { A: } 59^{\circ} \mathrm{C} / 1 \mathrm{~min} \\
\text { E: } 72^{\circ} \mathrm{C} / 1 \mathrm{~min} \\
\text { No of cycles:40 } \\
\text { FE: } 72^{\circ} \mathrm{C} / 5 \mathrm{mins}\end{array}$ & 205 & [53] \\
\hline $\begin{array}{l}\text { Candidatus Mycoplasma } \\
\text { haemobos }\end{array}$ & 16SrRNA & $\begin{array}{l}\text { F-GAGTTAGTTATTAAAGCTTTAT } \\
\text { R-ATTCATGAGGTACTATCAGTTG }\end{array}$ & $\begin{array}{l}\text { ID: } 94^{\circ} \mathrm{C} / 5 \mathrm{mins} \\
\text { D: } 94^{\circ} \mathrm{C} / 30 \mathrm{~s} \\
\text { A: } 55^{\circ} \mathrm{C} / 30 \mathrm{~s} \\
\text { E: } 72^{\circ} \mathrm{C} / 30 \mathrm{~s} \\
\text { No of cycles: } 40 \\
\text { FE: } 72^{\circ} \mathrm{C} / 7 \mathrm{mins}\end{array}$ & 279 & [49] \\
\hline
\end{tabular}

a negative control. Both positive and negative controls were included in each PCR run. PCR amplification was performed using the BioER Little Genius ${ }^{\bullet}$ LED Thermal Cycler (Hangzhou Bioer Technology China). The gel was stained with RedSafe ${ }^{\mathrm{TM}}$ (iNtRoN Biotechnology, Korea) for $10 \mathrm{~min}$, thereafter, amplified products were then analysed by electrophoresis on a $1.5 \%$ agar rose gel for $80 \mathrm{~min}$ at 80 voltage. The gel was visualised using a UV transilluminator (GeneDireX ${ }^{\mathrm{TM}}$, USA).

\section{Sequencing of PCR products and BLAST analysis}

Amplicons from each blood pathogen species with clear bright bands were selected for sequencing. They were gel extracted and purified using QIAquick gel extraction kit (Qiagen, Hilden, Germany) according to the manufacturers' protocol. The amplicons were sequenced using the BigDye ${ }^{\circledast}$ Terminator v3.1 cycle sequencing ready reaction kit (Applied Biosystems, USA). Consensus sequences were obtained for all PCR products using 
BioEdit Sequence Alignment Editor Software (version 7.0.5.3). The resulting nucleotide sequences were analysed and compared for similarities with reference sequences from GenBank database, using the Basic Local Alignment Search Tool (BLAST) program (http://www. ncbi.nlm.nih.gov/BLAST.cgi). PCR amplicons of 18SrRNA and 16SrRNA gene found to be negative for $T$. orientalis and A. marginale respectively were sequenced using their respective genus primer sets.

\section{Sequence alignment and phylogenetic analysis}

To determine the phylogenetic status of the various blood pathogen species identified in this study, a phylogenetic tree was constructed based on the MPSP gene of T. orientalis and T. sinensis for Theileria species, MSP4 gene of $A$. marginale, 16SrRNA gene of C. M. haemobos and RoTat1.2 VSG of T. evansi. Their sequences were supplemented with their respective reference sequences from GenBank and were aligned using ClustalW algorithm. After alignment, regions with gaps gap-free sites were used to construct phylogenetic trees using maximum likelihood method in MEGA software version $\mathrm{X}$ [55]. The reliability for the internal branches of maximum likelihood was assessed using 1000 bootstrap resamplings and molecular distances estimated by the general time reversible model [56].

\section{Statistical analysis}

All data, expressed as mean \pm standard error of mean, were normally distributed ( $P>0.05$, Shapiro-Wilk's test). Percentage occurrence of blood pathogens, both single and mixed infections, and 95\% confidence intervals were calculated using Proportion test (prop.test) in Epitools software (https://www.epitools.ausvet.com.au/ ciproportion). Chi-square test was used to determine the association between the presence of the blood pathogens and risk factors (gender and age of cattle). One-way multivariate analysis of variance (MANOVA), followed by Duncan multiple post hoc comparison test, was applied to study the effect of varying concentrations of saline solutions on erythrocytes. One-way analysis of variance (ANOVA) followed by Duncan post hoc comparison test were applied on the data generated from the haemato-biochemical parameters and mean cell fragility of the different groups of cattle. Mean cell fragility values were extrapolated from the erythrocyte osmotic fragility curves. Statistical analysis was performed using SPSS 25.0 (Chicago IL, USA). A Probability value $<0.05$ was considered as statistically significant. The KedahKelantan $\mathrm{x}$ Brahman cattle were later divided into eight categories based on the number of infecting blood pathogens; single species, double species co-infection, and triple species co-infection following PCR amplification and sequencing of species-specific genes.

\section{Accession numbers of nucleotide sequences}

The nucleotide sequences of all genes have been deposited in the GenBank of the NCBI database and assigned accession numbers are listed in Table 2.

\section{Results}

Clinical signs and microscopic examination of thin blood smears

Clinical signs such as anorexia, profuse ocular discharge, emaciation, weakness, and dyspnoea were observed in most of the sampled animals. Only two cattle were recumbent and had very poor body condition, cachexic and with less detectable body fat. Tail head, spine and ribs were prominent. The outline of spine and ribs of all other clinically ill cattle were slightly visible. Pallor of mucous membrane was observed in fifteen (15/61, 24.6\%) animals. No Theileria piroplasms or schizonts were detected in the blood cells. Anaplasma morula were absent in the erythrocytes and C. M. haemobos were not seen attached onto the surface of erythrocytes. Numerous T. evansi were seen in the thin blood smear as elongated extracellular protozoan parasites (Fig. 1A). The blood picture of all cattle group revealed the presence of echinocytes, elliptocytes, macrocytes, spherocytes, anisocytosis, few acanthocytes, rouleaux formation and immature neutrophils (metamyelocytes) (Figs. 1AF).

\section{Molecular identification, detection rate and similarity analysis of the blood pathogen strains detected in the KK $x$ Brahman cattle}

Molecular analysis by PCR amplification using genus specific primers produced expected fragment sizes of approximately $1750 \mathrm{bp}$ for $18 \mathrm{~S}$ rRNA gene of Theileria species, $345 \mathrm{bp}$ for 16SrRNA gene of Anaplasma species and $280 \mathrm{bp}$ for 16SrRNA gene of Mycoplasma species. Theileria species were detected in 44/61 cattle (72.13\%) and was the blood pathogen with the highest molecular detection rate, followed by Mycoplasma species in 25/61 (40.98\%) cattle, Anaplasma species in 16/61 cattle (26.23\%) and Trypanosoma evansi in 3/61 cattle (4.92\%) (Fig. 2). To identify and further confirm the specific species of blood pathogens detected in the cattle, PCR amplification using species-specific primers produced fragment of approximately $776 \mathrm{bp}$ of the major piroplasm surface protein (MPSP) gene of $T$. orientalis in 20/61 cattle (32.79\%), 761 bp of major surface protein 4 (MSP4) gene of $A$. marginale in $13 / 61$ cattle $(21.31 \%)$, 279 bp of 16SrRNA gene of C. M. haemobos in 25/61 cattle $(40.98 \%)$ and $205 \mathrm{bp}$ of RoTat1.2 VSG gene of $T$. evansi in 3/61cattle (4.92\%). Sequencing of T. orientalis PCR amplicons yielded 455-720 protein-coding nucleotides (MT184275-MT184279) and demonstrated between $98.17-99.80 \%$ molecular similarity with reference 
Table 2 GenBank accession numbers for the blood pathogens detected in this study

\begin{tabular}{|c|c|c|c|c|}
\hline No. & Blood pathogens & Genes & GenBank Accession No. & Sequence length (bp) \\
\hline 1 & Theileria orientalis & MPSP & $\begin{array}{l}\text { MT184275 } \\
\text { MT184276 } \\
\text { MT184277 } \\
\text { MT184278 } \\
\text { MT184279 }\end{array}$ & $\begin{array}{l}720 \\
455 \\
506 \\
455 \\
521\end{array}$ \\
\hline 2 & Theileria sinensis & $18 \mathrm{~S}$ rRNA & $\begin{array}{l}\text { MT271898 } \\
\text { MT271899 } \\
\text { MT271900 } \\
\text { MT271901 } \\
\text { MT271902 } \\
\text { MT271903 } \\
\text { MT271904 } \\
\text { MT271905 } \\
\text { MT271906 } \\
\text { MT271907 } \\
\text { MT271908 } \\
\text { MT271909 } \\
\text { MT271910 } \\
\text { MT271911 }\end{array}$ & $\begin{array}{l}1693 \\
1687 \\
1663 \\
1668 \\
1670 \\
1674 \\
1661 \\
1698 \\
1698 \\
1663 \\
1682 \\
1689 \\
1651 \\
1679\end{array}$ \\
\hline 3 & Theileria sinensis & MPSP & $\begin{array}{l}\text { MT240816 } \\
\text { MT240817 }\end{array}$ & $\begin{array}{l}871 \\
870\end{array}$ \\
\hline 4 & Anaplasma marginale & MSP4 & $\begin{array}{l}\text { MT173810 } \\
\text { MT173811 } \\
\text { MT173812 } \\
\text { MT173813 } \\
\text { MT173814 }\end{array}$ & $\begin{array}{l}672 \\
704 \\
705 \\
634 \\
704\end{array}$ \\
\hline 5. & Anaplasma platys & $16 \mathrm{~S}$ rRNA & $\begin{array}{l}\text { MT259465 } \\
\text { MT259466 }\end{array}$ & $\begin{array}{l}349 \\
348\end{array}$ \\
\hline 6. & Candidatus Mycoplasma haemobos & $16 \mathrm{~S}$ rRNA & $\begin{array}{l}\text { MT521752 } \\
\text { MT521753 }\end{array}$ & $\begin{array}{l}248 \\
253\end{array}$ \\
\hline 7 & Trypanosoma evansi & RoTaT 1.2 VSG & $\begin{array}{l}\text { MT514513 } \\
\text { MT514514 }\end{array}$ & $\begin{array}{l}203 \\
204\end{array}$ \\
\hline
\end{tabular}

sequences from Thailand (AB562570.1), Vietnam (LC125432.1), Sri Lanka (LC438477.1; AB701444.1), Myanmar (AB871365.1), China (KU356867.1). Twentyfour out of fourty-four (44) Theileria species PCR amplicons, which were negative for $T$. orientalis were amplified using the $18 \mathrm{~S}$ rRNA gene primer sets. Fourteen out of 24 amplicons were randomly selected for sequencing and yielded between 1651 and 1698 nucleotides. Similarity analysis using nucleotide BLAST (BLASTn) demonstrated that those fourteen (14) negative T. orientalis PCR amplicons corresponded to T. sinensis (MT271898 - MT271911), and shared a high degree of molecular similarity (99.5-99.87\%) in comparison with reference sequences from China (KF559355.1; EU274472.1; HM538203.1), 99.7\% similarity with reference strain from Johore Malaysia (KX263953.1) and 99.65\% similarity with Thailand strain (MH156036.1).

The sixteen (16) positive $16 \mathrm{~S}$ ribosomal RNA gene of Anaplasma species strains further subjected to a species-specific PCR using MSP4 primer set, revealed that 13 out of 16 amplicons were positive for A. marginale. Five representative amplicon sequences (MT173810 - MT173814) for MSP4 gene of A. marginale yielded 634-704 protein-coding nucleotides and demonstrated
99-100\% similarity for $A$. marginale reference sequences from Western Cuba (MK809386), Brazil (KM624516), Thailand (MK140740) and India (KX989516). The 2 out of 3 amplicons negative for $A$. marginale were sequenced using $16 \mathrm{~S}$ rRNA primer set and demonstrated 99\% similarity for $A$. platys reference sequences from China (KU586159.1) and Brazil (JX392984.1), and 98\% similarity with $A$. platys strains from India (MG050139.1). The A. platys strains MT259465 \& MT259466 from this study had 98.03\% similarity with reference $A$. platys strain (MH686048.1) detected in two Vietnamese cattle [23]. A 99.24\% molecular similarity existed between $A$. platys strains from this study and other $A$. platys strains from stray dogs in several Malaysian states; Sarawak (KU500914.1), Selangor (KU500912.1), Sabah (KU500909.1), Pahang (KU500906.1), Pinang (KU500905.1), Kedah (KU500904.1) and Johor (KU500902.1). A. platys strains from this study also demonstrated $100 \%$ similarity with A. platys Malaysian strain (MH368782) adapted from Koh et al. [57].

16SrRNA gene sequences of $C$. M. haemobos strains (MT521752 - MT521753) from this study shared 100\% molecular similarity with reference strains from Malaysia 

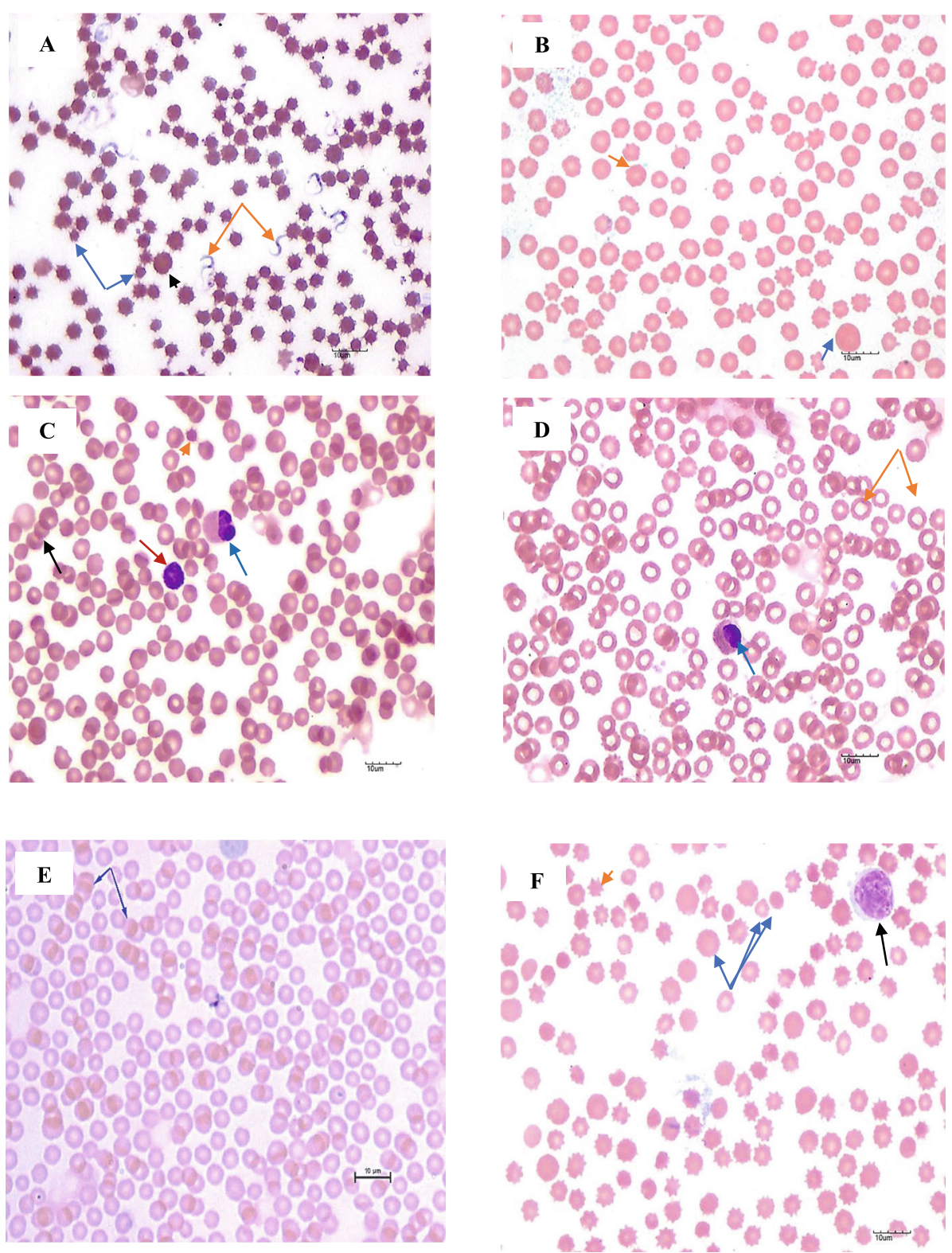

Fig. 1 Micrographs of stained-blood smears from selected blood pathogen species infected Kedah-Kelantan $x$ Brahman cattle groups from Muadzam Pahang Malaysia (× 1000 magnification). Confirmation of the types of blood pathogens were based on PCR and sequence analysis of the PCR amplicons (A) Double-orange arrow shows Trypanosoma evansi in a Wright-stained thin blood smear of Kedah-Kelantan X Brahman cattle. Anisocytosis with mixture of large (macrocytes), normal and small (spherocytes) erythrocytes are prominent; the presence of echinocytes of this blood smear are more related to drying effect. Double-blue arrow shows spherocytes while black arrow head shows a macrocyte (B) A Wright-stained thin blood smear from Anaplasma platys + Theileria sinensis double species co-infected cattle showing the presence of echinocytes (orange arrow represents one of the ecchinocytes) and a macrocyte (blue arrow). Poikilocytosis and anisocytosis are evident. (C) A Wright-stained thin blood smear from Anaplasma marginale + T. orientalis double species co-infected cattle showing spherocyte (orange-arrow head)metamyelocyte (blue arrow), and lymphocyte (red arrow) with background erythrocytes of different sizes (anisocytosis), and rouleaux formation (black arrow). (D) Wright-stained thin blood smears from Theileria orientalis + T. sinensis double species co-infected cattle showing numerous erythrocytes with wide central pallor (hypochromasia) and different sizes (anisocytosis). Blue arrow shows a metamyelocyte (E) Wrightstained thin blood smear of C. M. haemobos + T. sinensis double species co-infected cattle showing marked rouleaux formation with normal erythrocyte size. (F) Thin blood smear from C. M. haemobos + T. sinensis + A. marginale triple species co-infected cattle showing poikilocytosis and anisocytosis (represented by triple blue arrows). Large lymphocyte (black arrow) and erythrocytes of varying sizes [(macrocytes, normal and spherocytes (triple blue arrows)], poikilocytosis and hypochromasia are evident. Orange arrowhead shows an echinocyte. Note: Macrocytes reflect the regenerative response of anaemia, spherocytes reflect an immune-mediated haemolytic anaemia (IMHA) state, metamyelocytes (indicates moderate left shift) and rouleaux formation reflect a systemic inflammatory response in the cattle 


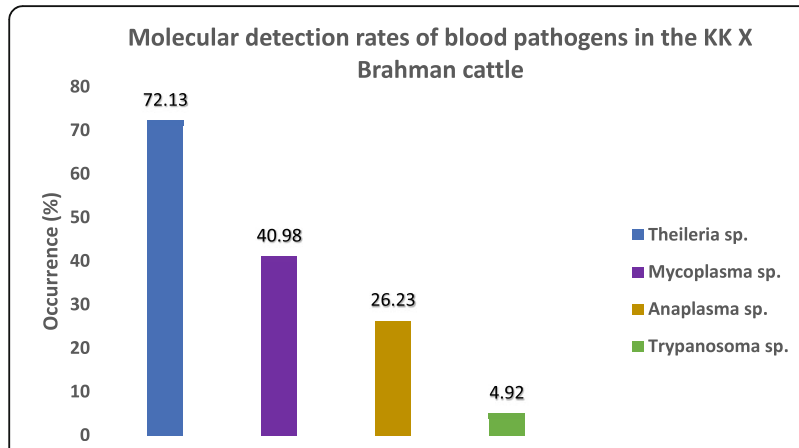

Fig. 2 Molecular detection rates of Theileria, Mycoplasma, Anaplasma and Trypanosoma species confirmed by PCR amplification and sequencing in the Kedah-Kelantan $\times$ Brahman cattle sampled in Muadzam Pahang Malaysia

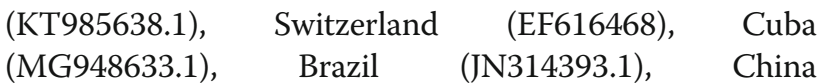
(MH388479.1), Mozambique (MF992084.1), Philippines (MK328955.1) and 99.57\% similarity with reference sequence from Japan (EU367965.1). Amplicon sequences for RoTat1.2 VSG gene of T. evansi strains from this study (MT514513-MT514514) demonstrated 100\% molecular similarity with strains from Kenya (MK867832; MK867833), India (KY457409.1) and Egypt (KF726106; JX888091). No significant similarity was found between our strains and local Malaysian T. evansi strains (JN247439.1; AM497933.1; AM497934.1).

\section{Percentage occurrence of single, double and triple} species co-infection in Kedah-Kelantan $\mathrm{x}$ Brahman cattle A total of six species of blood pathogens were detected by PCR and sequencing of amplicons and these include T. orientalis, T. sinensis, A. marginale, A. platys, C. M. haemobos and $T$. evansi. Detection rate of single and mixed blood pathogen infection are presented in Table 3. Analysis of blood pathogen single species infection among the sampled cattle revealed that $14.75 \%$ were infected by $T$. sinensis while sole infections with C. $M$. haemobos infected cattle and T. evansi were 8.20 and
4.92\% respectively. Theileria sinensis $+C$. M. haemobos had the highest double species co-infection (27.87\%), followed by $T$. orientalis $+A$. marginale $(16.39 \%), T$. orientalis $+T$. sinensis $(14.75 \%)$, and the lowest being $A$. platys $+T$. sinensis (4.92\%) (Table 3). C. Mycoplasma haemobos $+T$. sinensis $+A$. marginale triple species coinfection was detected in (8.20\%) of the sampled cattle. T. sinensis + C. M. haemobos species co-infection had the highest occurrence while C.M. haemobos $+T$. sinensis $+A$. marginale triple species co-infection was the least (Table 3). Forty-four cattle $(72.13 \%)$ were infected with more than one blood pathogen. There were no significant association between molecular presence of the blood pathogens and age $\left(\mathrm{X}^{2}=23.001 ; p=0.060\right)$ or blood pathogens and gender $\left(\chi^{2}=9.524 ; p=0.217\right)$.

\section{Phylogenetic analysis}

Phylogenetic analysis was done to determine whether the vector-borne blood pathogens detected in this study are genetically diverse within different geographical regions of the world. Phylogenetic analysis based on the MPSP gene of $T$. orientalis grouped our Malaysian strains, MT184277 and MT184279 together with reference strains from China (KX375396.1; KU356867.1), Vietnam (LC125432.1), Thailand (AB562570) and Myanmar (AB871365.1) in a subclade. Thailand (KU886290.1; KU886285.1), Sri Lanka (AB701444; LC438477.1) and Mongolia (AB602388.1) reference strains grouped together and formed a subclade with our Malaysian strains MT184275, MT184276 and MT184278 (Fig. 3). The MPSP gene sequences of $T$. sinensis (MT250816-7) from this study grouped together with sequences from Jilin China (MN630027.1), Xinjiang China (MG950147.1), Gansu China (MG784422; GQ180193.1) and Yanji China (KX375402.1) (Fig. 3) but formed a separate branch with our five T. orientalis MPSP gene sequences (MT259465MT259466),.

Phylogenetic analysis based on MSP4 gene grouped $A$. marginale strains (MT173810-MT173814) from this

Table 3 Percentage occurrence of single and mixed blood pathogen infections in Kedah-Kelantan x Brahman cattle

\begin{tabular}{lll}
\hline Blood Pathogens & No of cattle positive for blood pathogens & Occurrence (\%) (95\% Cl) \\
\hline Trypanosoma evansi & 3 & $4.92(1.69-13.49)$ \\
C. Mycoplasma haemobos & 5 & $8.20(3.55-17.79)$ \\
Theileria sinensis & 9 & $14.75(7.96-25.72)$ \\
Theileria orientalis + Anaplasma marginale & 10 & $16.39(9.16-27.61)$ \\
Anaplasma platys + Theileria sinensis & 3 & $4.92(1.69-13.49)$ \\
Theileria sinensis + C. Mycoplasma haemobos & 17 & $27.87(18.19-40.17)$ \\
Theileria orientalis + Theileria sinensis & 9 & $14.75(7.96-25.72)$ \\
C. M. haemobos + T. sinensis + A. marginale & 5 & $8.20(3.55-17.79)$ \\
\hline
\end{tabular}

$\mathrm{Cl}$ Confidence Interval. Total number of clinically ill cattle $=61$. Total number of blood pathogen positive cattle $=61$. Total number of cattle with more than one blood pathogen infection $=44$ 


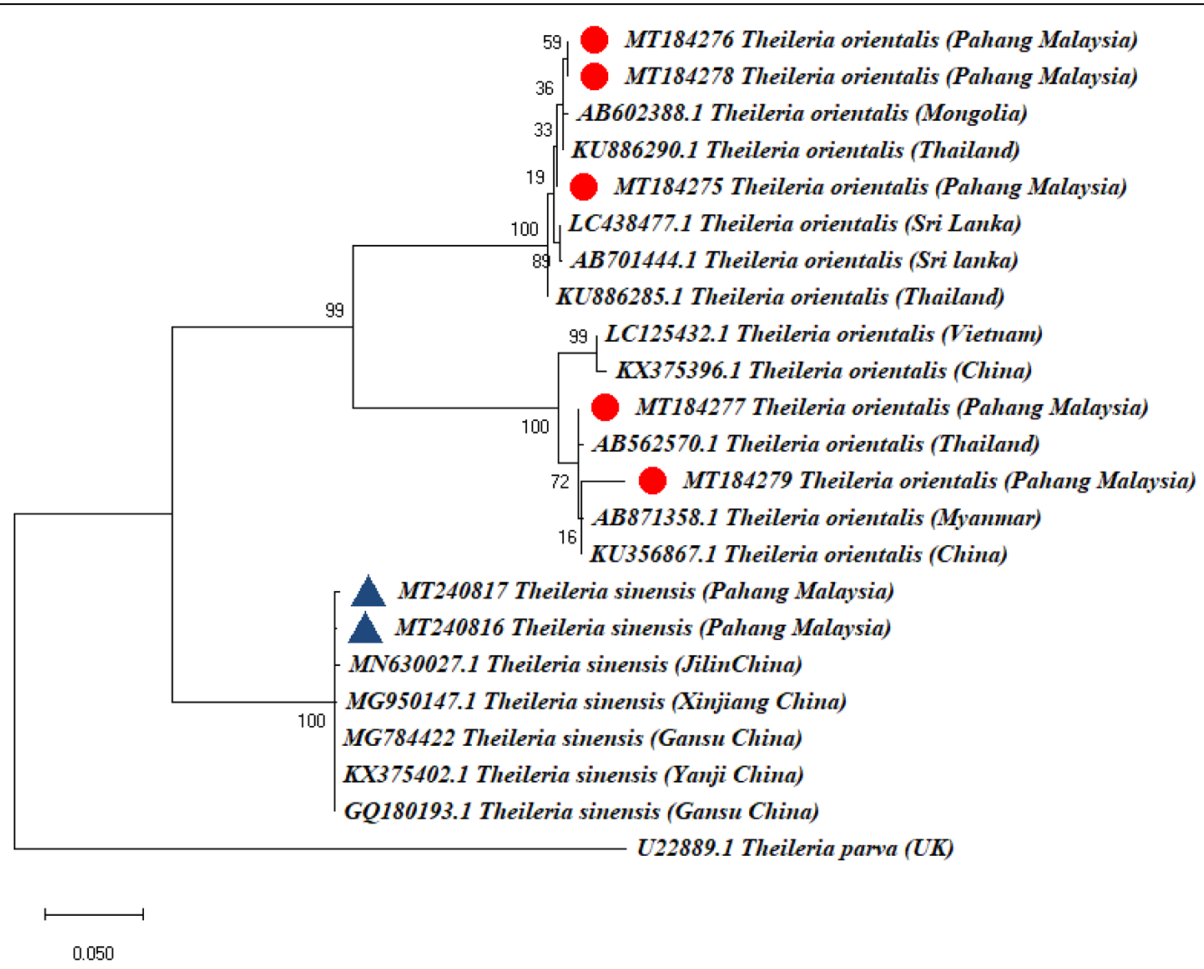

Fig. 3 Phylogenetic tree showing taxonomic relationships of Theileria orientalis and Theileria sinensis detected from Kedah Kelantan x Brahman cattle in Muadzam Pahang Malaysia. The phylogenetic relationships were inferred based on MPSP gene (455-720 bp) from five (5) sequences of T. orientalis and two (2) MPSP gene sequences of T. sinensis (871-872 bp). Theileria parva was used as an outgroup. Phylogenetic reconstruction was performed in MEGA X using maximum likelihood analysis based on the general time-reversible model. Support for each node was indicated by 1000 bootstrap resamplings. The scale bar represents the number of substitutions per site. The accession numbers are given at beginning of each sequence label, followed by the full species names and country, in parenthesis, from where they were obtained. Five (5) T. orientalis and two (2) T. sinensis strains from Muadzam Pahang Malaysia are marked with a solid red circle and blue triangles respectively

study together with reference sequences from Mozambique (MH172467.1; MH026093.1), Colombia (MF771080.1), Thailand (MK140740.1), India (KX989517; MG676459.1), Brazil (MK570463.1) and Cuba (MK809386.1) (Fig. 4). Five A. marginale MSP4 gene sequences from this study formed separate branches with A. phagocytophilim Malaysian strains (MG988295.1-MG988296.1) (Fig. 4).

$16 \mathrm{~S}$ rRNA reference gene sequences of C. M. haemobos from China (MH388479.1), Japan (EU367965.1), Malaysia (KT985638.1), Switzerland (EF616468.1), Rondonia (KT314241.1), Cuba (MG948633.1), Mozambique (MF992084.1), Brazil (JN314393.1), Philippines (MK328955.1) and Nigeria (MH631456.1) were tightly grouped together with C. M. haemobos strains from this study (MT521752 - MT521753). Mycoplasma wenyonii strains from Iraq (MK422446.1), Switzerland (GQ259756.1) and Malaysia (KT990216-KT990217.1) formed a separate branch from the C. M. haemobos strains from this study (Fig. 5). Phylogenetic analysis revealed that the 2 Trypanosoma evansi RoTat1.2 VSG sequences from this study (MT514513 and MT514514) grouped together with reference strains from Egypt
(KF726106.1; JX888091.1), India (KY457409), Kenya (MK867832.1-MK867833.1) and Japan (LC493168.1; LC493171.1). Surprisingly, the three Malaysian reference T. evansi strains (JN247439.1; AM497933.1AM497934.1) formed a separate branch from the $T$. evansi strains obtained from this study (Fig. 6).

\section{Haemato-biochemical and electrolyte abnormalities in the different cattle groups}

The haematology and serum biochemistry profile of sampled KK x Brahman crossbred cattle are presented in Tables 4 and 5. Anaemia was detected in 15/61 cattle (24.59, 95\% CI 15.51-36.68\%) and icterus in 3/61 cattle (4.92, 95\% CI 1.69-13.49\%). The cattle were divided into eight groups namely T. evansi infected cattle; C. M. haemobos infected cattle; $T$. sinensis infected cattle; $T$. orientalis + A. marginale infected cattle; A. platys $+T$. sinensis infected cattle; T. sinensis + C. M. haemobos; $T$. orientalis $+T$. sinensis infected cattle; C. M. haemobos + T. sinensis $+A$. marginale infected cattle groups. A significant $(p<0.05)$ decrease in mean PCV, RBC, Hb and high mean cell volume (MCV), icteric index and a normal $\mathrm{MCHC}$ value were recorded for the $T$. evansi 


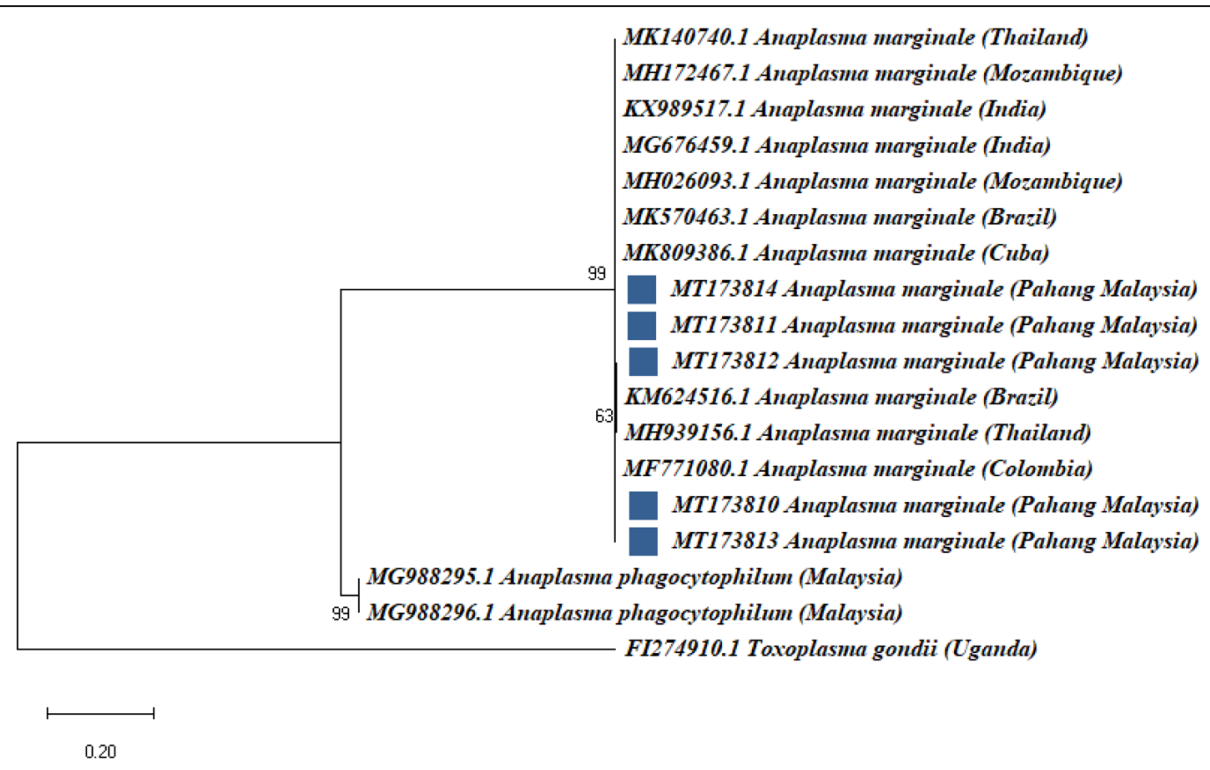

Fig. 4 Maximum Likelihood analysis of MSP4 gene of A. marginale sequences showing the phylogenetic relationship of the Anaplasma species. The phylogenetic relationship was inferred based on MSP4 gene (634-704 bp) from five (5) sequences of A. marginale strains, ten MSP4 reference gene sequences of A. marginale and two A. phagocytophilum MSP4 gene sequences. Toxoplasma gondii was used as an outgroup. The scale bar represents the number of substitutions per site. For each sequence, the accession numbers are given at beginning of each sequence label, the full species names are followed up by the country in parenthesis where they were obtained. Five A. marginale strains detected in Kedah-Kelantan $x$ Brahman cross bred cattle in Pahang Malaysia are marked with a solid blue square

infected group. Plasma protein value was significantly $(p<0.05)$ elevated in all cattle groups with that of the $T$. evansi being highest when compared to the clinically healthy cattle. Cattle positive for $T$. sinensis sole infection had significantly $(p<0.05)$ low mean $\mathrm{RBC}, \mathrm{Hb}, \mathrm{PCV}$ values and normal icteric index. Significantly $(p<0.05)$ decreased mean RBC count and $\mathrm{Hb}$ values with a high $\mathrm{MCV}$ and normal PCV values were recorded in the $A$. platys $+T$. sinensis cattle group. Significant $(P<0.05)$ increase in mean plasma protein values were recorded in all infected cattle groups when compared to clinically healthy cattle. There were no significant $(p>0.05)$ differences in the mean values of MCHC and platelet count of all cattle groups. All blood pathogen infected cattle groups had significantly $(p<0.05)$ high mean myelocyte, metamyelocyte, band and segmented neutrophil values when compared to the clinically healthy cattle (Table 4 ). Significant $(p<0.05)$ increase in mean values of sodium, potassium and chloride were recorded across all infected cattle groups, with a significant increase in mean creatinine and urea values recorded only for the $T$. evansi infected cattle group (Table 5). Significant $(p<0.05)$ increases in mean serum ALP, AST, GGT activities, globulin, total and conjugated bilirubin, and decreased mean serum albumin value were observed in the T. evansi cattle group when compared to the other infected groups and clinically healthy cattle group (Table 5). The mean serum alkaline phosphatase (ALP) value of the $T$. sinensis infected cattle was lower than that of all the cattle groups. Mean serum total protein and globulin values were increased in the T. evansi, C. M. haemobos and T. orientalis $+A$. marginale infected cattle groups. Low albumin with low albumin to globulin ratio (A:G) was recorded in the T. evansi group, while albumin to globulin ratio (A:G) was decreased across all cattle groups. Significant $(p<0.05)$ increases in the mean serum total and unconjugated bilirubin values of the T. evansi cattle were recorded when compared to the other cattle groups (Table 5).

\section{Mean erythrocyte osmotic fragility}

The erythrocyte osmotic fragility (EOF) curves of all infected cattle groups showed an evident shift to the right, when compared to the clinically healthy cattle (Fig. 7). Duncan's post hoc comparison test showed an increase of erythrocyte osmotic fragility at $0,0.1,0.3,0.5,0.7$ and $0.9 \%$ saline concentration in all infected cattle groups (Fig. 7). The mean cell fragility (MCF) values of all the infected cattle groups were significantly $(p<0.05)$ higher than that of the clinically healthy cattle (Fig. 8).

\section{Discussion}

Clinical signs observed in clinically ill cattle such as anaemia, anorexia, emaciation, profuse ocular discharges, loss of body condition, and recumbency are usually associated with blood pathogen infections in cattle $[1-3,17$, 58]. In the present study, T. orientalis, $T$. sinensis, $A$. marginale, A. platys, C. Mycoplasma haemobos, and T. 


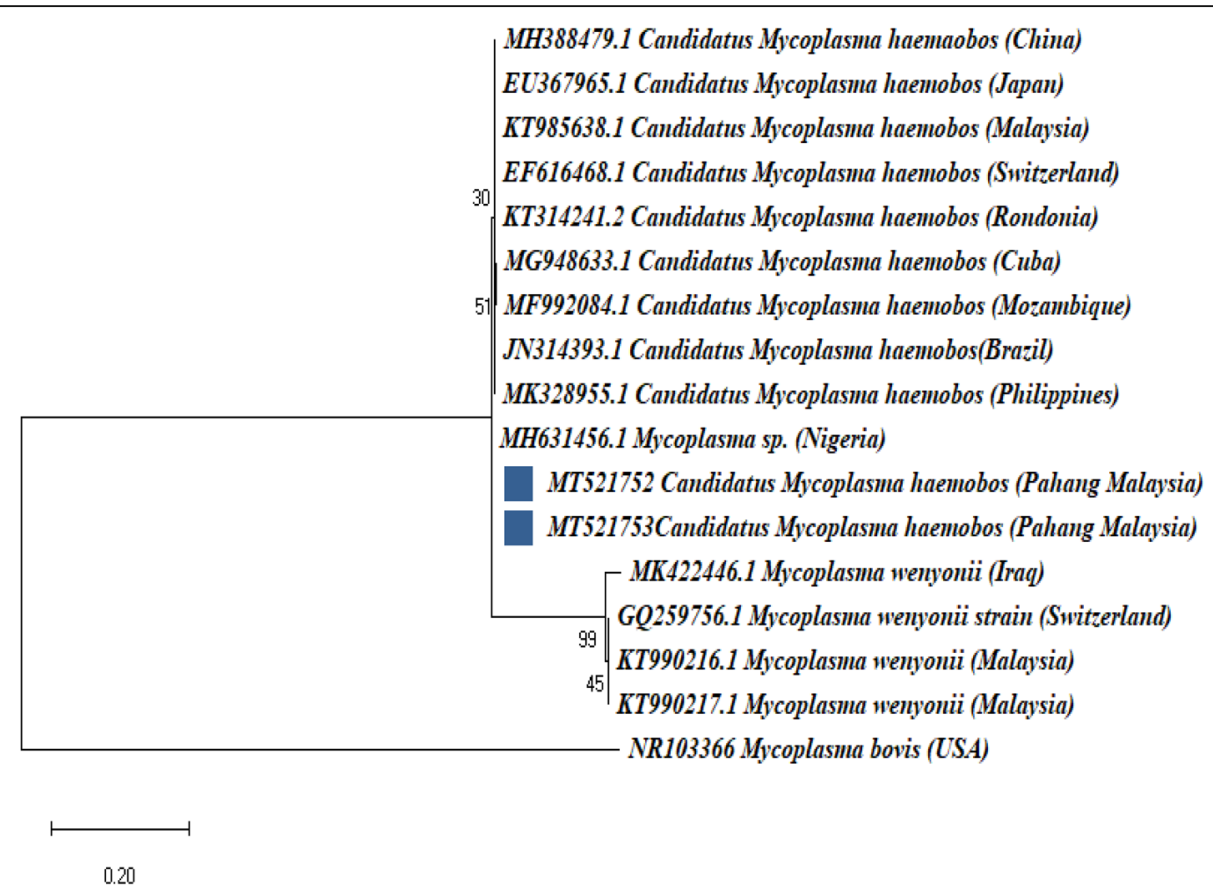

Fig. 5 Phylogenetic tree showing taxonomic relationships of Candidatus Mycoplasma haemobos detected from KK x Brahman cattle in Pahang Malaysia. The relationships were inferred based on 16SrRNA gene sequences from two (2) C. M. haemobos (248 bp \& 253 bp), ten (10) reference sequences of C. Mycoplasma haemobos and four reference sequences of Mycoplasma wenyonii. Mycoplasma bovis was used as an outgroup. Phylogenetic reconstruction was performed in MEGA X using maximum likelihood analysis based on the general time-reversible model. Support for each node was indicated by 1000 bootstrap resamplings. The scale bar represents the number of substitutions per site. For each sequence, the full species names are followed up by the country where they were isolated. The accession numbers are given at beginning of each sequence label. Two C. Mycoplasma haemobos strains from Pahang Malaysia are marked with a solid blue square

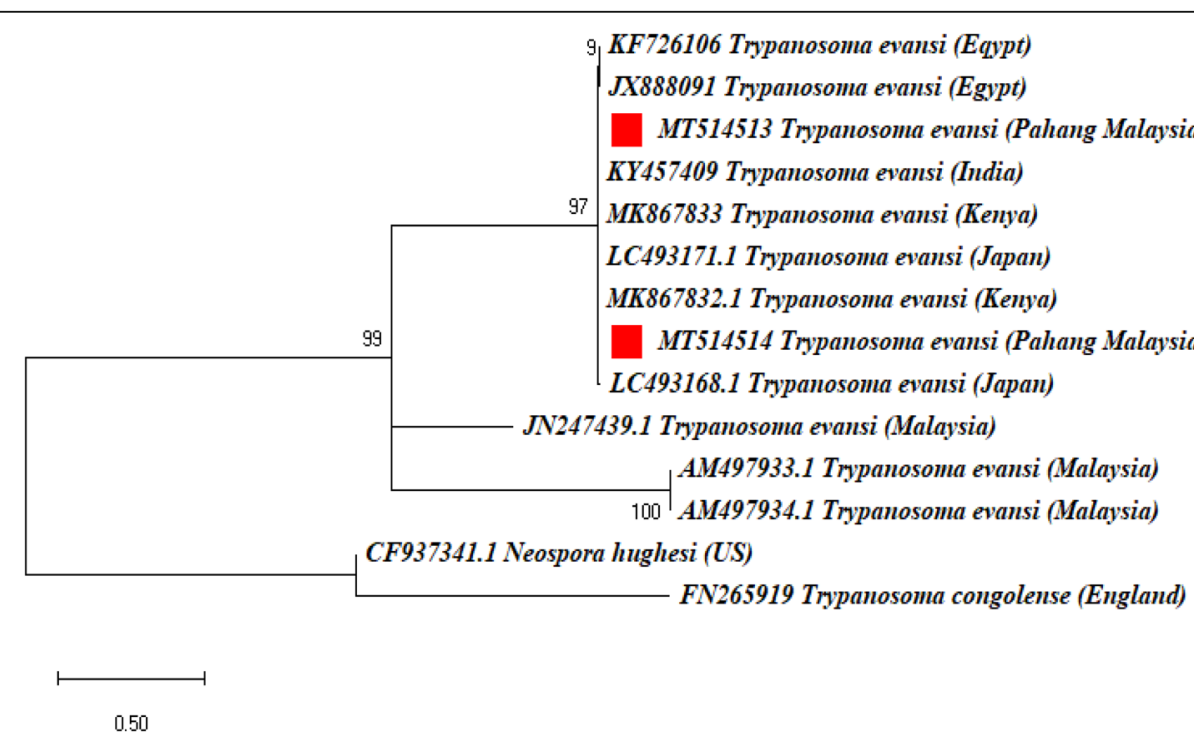

Fig. 6 Phylogenetic tree showing taxonomic relationships of Trypanosoma evansi detected from KK x Brahman cattle in Muadzam Pahang Malaysia. The relationships were inferred based on RoTat1.2 VSG gene (203-204 bp) from two T. evansi from Pahang Malaysia and 10 reference sequences of T. evansi. Neospora hughesi and Trypanosoma congolense were used as outgroup. Phylogenetic reconstruction was performed in MEGA X using maximum likelihood analysis based on the general time-reversible model. Support for each node was indicated by 1000 bootstrap resamplings. The scale bar represents the number of substitutions per site. For each sequence, the full species names are followed up by the country where they were isolated. The accession numbers are given at beginning of each sequence label. Two (2) Trypanosoma evansi strains detected in the cattle from Muadzam Pahang Malaysia are marked with a solid red square 
Table 4 Haematological parameters of KK x Brahman cattle naturally infected by blood pathogens

\begin{tabular}{|c|c|c|c|c|c|c|c|c|c|}
\hline $\begin{array}{l}\text { Haematological } \\
\text { Parameters }\end{array}$ & $\begin{array}{l}\text { T. evansi } \\
\text { infected } \\
\text { cattle } \\
(n=3)\end{array}$ & $\begin{array}{l}\text { Candidatus } \\
\text { M. } \\
\text { haemobos } \\
\text { infected } \\
\text { cattle } \\
(n=5)\end{array}$ & $\begin{array}{l}T . \\
\text { sinensis } \\
\text { infected } \\
\text { cattle } \\
(n=9)\end{array}$ & $\begin{array}{l}T . \\
\text { orientalis }+ \\
\text { A. marginale } \\
\text { infected } \\
\text { cattle } \\
(n=10)\end{array}$ & $\begin{array}{l}\text { A. platys }+ \\
T . \text { sinensis } \\
\text { infected } \\
\text { cattle } \\
(n=3)\end{array}$ & $\begin{array}{l}\text { T. sinensis + } \\
\text { C. M. } \\
\text { haemobos } \\
\text { infected } \\
\text { cattle }(n= \\
\text { 17) }\end{array}$ & $\begin{array}{l}T . \\
\text { orientalis + } \\
T . \text { sinensis } \\
\text { infected } \\
\text { cattle ( } n= \\
\text { 9) }\end{array}$ & $\begin{array}{l}\text { C. } M . \\
\text { haemobos }+T . \\
\text { sinensis }+A . \\
\text { marginale } \\
\text { infected cattle } \\
(n=5)\end{array}$ & $\begin{array}{l}\text { Clinically } \\
\text { healthy } \\
\text { cattle } \\
(n=17)\end{array}$ \\
\hline PCV (L/L) & $\begin{array}{l}0.20 \pm \\
0.01^{\mathrm{a}}\end{array}$ & $0.32 \pm 0.04^{c}$ & $\begin{array}{l}0.23 \pm \\
0.01^{\mathrm{ab}}\end{array}$ & $0.33 \pm 0.02^{c d}$ & $0.32 \pm 0.06^{c}$ & $0.33 \pm 0.01^{c d}$ & $0.34 \pm 0.02^{c d}$ & $0.30 \pm 0.02^{\mathrm{bc}}$ & $\begin{array}{l}0.40 \pm \\
0.01^{d}\end{array}$ \\
\hline $\begin{array}{l}\text { RBC count }(\times \\
\left.10^{12} / L\right)\end{array}$ & $\begin{array}{l}3.03 \pm \\
0.03^{\mathrm{a}}\end{array}$ & $6.47 \pm 0.38^{b c d}$ & $\begin{array}{l}3.86 \pm \\
0.37^{\mathrm{a}}\end{array}$ & $5.83 \pm 0.45^{b c}$ & $4.78 \pm 0.45^{\mathrm{ab}}$ & $7.05 \pm 0.41^{c d}$ & $\begin{array}{l}6.47 \pm \\
0.52^{\mathrm{bcd}}\end{array}$ & $6.11 \pm 0.51^{\mathrm{bcd}}$ & $\begin{array}{l}8.05 \pm \\
0.23^{d}\end{array}$ \\
\hline $\begin{array}{l}\text { Haemoglobin } \\
\text { (g/L) }\end{array}$ & $\begin{array}{l}62.50 \pm \\
0.50^{\mathrm{a}}\end{array}$ & $\begin{array}{l}84.33 \pm \\
0.50^{\mathrm{bcd}}\end{array}$ & $\begin{array}{l}67.88 \pm \\
2.82^{\mathrm{ab}}\end{array}$ & $95.63 \pm 4.84^{\mathrm{cd}}$ & $\begin{array}{l}78.00 \pm \\
0.00^{\mathrm{abc}}\end{array}$ & $103.00 \pm 3.78^{d}$ & $\begin{array}{l}87.00 \pm \\
5.99^{\mathrm{bcd}}\end{array}$ & $86.00 \pm 2.35^{b c}$ & $\begin{array}{l}126.14 \pm \\
2.02^{\mathrm{e}}\end{array}$ \\
\hline MCV (fL) & $\begin{array}{l}66.09 \pm \\
2.76^{\mathrm{bc}}\end{array}$ & $48.68 \pm 5.54^{\mathrm{a}}$ & $\begin{array}{l}54.56 \pm \\
3.28^{\mathrm{ab}}\end{array}$ & $58.63 \pm 3.43^{\mathrm{abc}}$ & $\begin{array}{l}68.79 \pm \\
3.14^{\mathrm{C}}\end{array}$ & $49.75 \pm 2.53^{\mathrm{a}}$ & $\begin{array}{l}54.77 \pm \\
3.83^{\mathrm{ab}}\end{array}$ & $54.23 \pm 7.01^{\mathrm{ab}}$ & $\begin{array}{l}49.31 \pm \\
1.02^{\mathrm{a}}\end{array}$ \\
\hline MCHC (g/L) & $\begin{array}{l}328.00 \pm \\
4.00\end{array}$ & $339.75 \pm 6.32$ & $\begin{array}{l}293.03 \pm \\
5.79\end{array}$ & $329.67 \pm 4.26$ & $\begin{array}{l}321.00 \pm \\
3.00\end{array}$ & $330.83 \pm 5.75$ & $329.78 \pm 4.26$ & $330.83 \pm 5.76$ & $\begin{array}{l}311.53 \pm \\
1.11\end{array}$ \\
\hline $\begin{array}{l}\text { Plasma proteins } \\
\text { (g/L) }\end{array}$ & $\begin{array}{l}109.00 \pm \\
1.41^{c}\end{array}$ & $86.25 \pm 5.07^{\mathrm{ab}}$ & $\begin{array}{l}91.11 \pm \\
2.65^{\mathrm{ab}}\end{array}$ & $93.60 \pm 4.11^{b}$ & $\begin{array}{l}95.00 \pm \\
5.00^{\mathrm{b}}\end{array}$ & $95.35 \pm 3.10^{\mathrm{b}}$ & $\begin{array}{l}90.63 \pm \\
4.12^{\mathrm{ab}}\end{array}$ & $89.50 \pm 4.11^{\mathrm{ab}}$ & $\begin{array}{l}77.13 \pm \\
1.15^{\mathrm{a}}\end{array}$ \\
\hline $\begin{array}{l}\text { Icteric index } \\
\text { (units) }\end{array}$ & $\begin{array}{l}50.00 \pm \\
0.00^{\mathrm{b}}\end{array}$ & $5.00 \pm 0.00^{\mathrm{a}}$ & $\begin{array}{l}5.00 \pm \\
0.00^{\mathrm{a}}\end{array}$ & $5.00 \pm 0.00^{\mathrm{a}}$ & $5.00 \pm 0.00^{a}$ & $5.00 \pm 0.00^{\mathrm{a}}$ & $5.00 \pm 0.00^{\mathrm{a}}$ & $5.00 \pm 0.00^{\mathrm{a}}$ & $\begin{array}{l}5.00 \pm \\
0.00^{\mathrm{a}}\end{array}$ \\
\hline $\begin{array}{l}\text { Platelets ( } \\
\left.10^{9} / \mathrm{L}\right)\end{array}$ & $\begin{array}{l}321.50 \pm \\
6.50^{\mathrm{a}}\end{array}$ & $\begin{array}{l}392.00 \pm \\
2.36^{\mathrm{a}}\end{array}$ & $\begin{array}{l}378.11 \pm \\
7.42^{\mathrm{a}}\end{array}$ & $357.44 \pm 5.01^{\mathrm{a}}$ & $\begin{array}{l}420.00 \pm \\
7.00 \mathrm{ab}\end{array}$ & $458.72 \pm 6.59^{\mathrm{ab}}$ & $\begin{array}{l}322.25 \pm \\
9.89^{\mathrm{a}}\end{array}$ & $600.33 \pm 8.61^{b}$ & $\begin{array}{l}461.51 \pm \\
3.35^{\text {ab }}\end{array}$ \\
\hline $\begin{array}{l}\text { WBC count }(x \\
\left.10^{9} / L\right)\end{array}$ & $\begin{array}{l}4.94 \pm \\
0.28\end{array}$ & $5.22 \pm 0.65$ & $\begin{array}{l}5.07 \pm \\
0.58\end{array}$ & $4.97 \pm 0.93$ & $6.96 \pm 0.72$ & $6.75 \pm 0.59$ & $6.91 \pm 0.54$ & $6.36 \pm 0.97$ & $\begin{array}{l}7.30 \pm \\
0.30\end{array}$ \\
\hline $\begin{array}{l}\text { Lymphocyte (X } \\
\left.10^{9} / \mathrm{L}\right)\end{array}$ & $\begin{array}{l}3.97 \pm \\
0.42\end{array}$ & $4.08 \pm 0.71$ & $\begin{array}{l}3.81 \pm \\
0.50\end{array}$ & $3.66 \pm 0.52$ & $5.47 \pm 0.67$ & $5.88 \pm 0.52$ & $5.24 \pm 0.56$ & $4.98 \pm 0.82$ & $2.5-7.5$ \\
\hline $\begin{array}{l}\text { Promyelocyte } \\
\left(\times 10^{9} / \mathrm{L}\right)\end{array}$ & $\begin{array}{l}0.00 \pm \\
0.00^{\mathrm{a}}\end{array}$ & $0.00 \pm 0.00^{a}$ & $\begin{array}{l}0.01 \pm \\
0.00^{\mathrm{ab}}\end{array}$ & $0.00 \pm 0.00^{a}$ & $0.03 \pm 0.01^{b}$ & $0.01 \pm 0.00^{\mathrm{ab}}$ & $0.00 \pm 0.00^{\mathrm{a}}$ & $0.00 \pm 0.00^{\mathrm{a}}$ & $\begin{array}{l}0.00 \pm \\
0.00^{\mathrm{a}}\end{array}$ \\
\hline $\begin{array}{l}\text { Myelocyte (X } \\
\left.10^{9} / \mathrm{L}\right)\end{array}$ & $\begin{array}{l}0.12 \pm \\
0.07^{\mathrm{a}}\end{array}$ & $0.15 \pm 0.09^{\mathrm{ab}}$ & $\begin{array}{l}0.20 \pm \\
0.06^{\mathrm{ab}}\end{array}$ & $0.40 \pm 0.18^{\mathrm{ab}}$ & $0.16 \pm 0.02^{\mathrm{ab}}$ & $0.14 \pm 0.04^{\mathrm{ab}}$ & $0.34 \pm 0.13^{\mathrm{ab}}$ & $0.08 \pm 0.05^{\mathrm{ab}}$ & $\begin{array}{l}0.00 \pm \\
0.00^{\mathrm{a}}\end{array}$ \\
\hline $\begin{array}{l}\text { Metamyelocyte } \\
\left(\times 10^{9} / \mathrm{L}\right)\end{array}$ & $\begin{array}{l}0.40 \pm \\
0.03^{d}\end{array}$ & $0.22 \pm 0.08^{\mathrm{bc}}$ & $\begin{array}{l}0.26 \pm \\
0.10^{\mathrm{bcd}}\end{array}$ & $0.20 \pm 0.04^{b c}$ & $0.29 \pm 0.02^{c d}$ & $0.12 \pm 0.03^{\mathrm{abc}}$ & $\begin{array}{l}0.16 \pm \\
0.04^{\mathrm{abc}}\end{array}$ & $0.15 \pm 0.08^{\mathrm{abc}}$ & $\begin{array}{l}0.00 \pm \\
0.00^{\mathrm{a}}\end{array}$ \\
\hline Band $\left(\times 10^{9} / \mathrm{L}\right)$ & $\begin{array}{l}0.27 \pm \\
0.11^{\mathrm{abc}}\end{array}$ & $0.66 \pm 0.06^{a}$ & $\begin{array}{l}0.34 \pm \\
0.08^{\mathrm{bcc}}\end{array}$ & $0.39 \pm 0.11^{b c}$ & $\begin{array}{l}0.25 \pm \\
0.06^{\mathrm{abc}}\end{array}$ & $0.29 \pm 0.05^{\mathrm{abc}}$ & $0.52 \pm 0.14^{c}$ & $0.85 \pm 0.07^{c}$ & $\begin{array}{l}0.00 \pm \\
0.00^{\mathrm{a}}\end{array}$ \\
\hline $\begin{array}{l}\text { Segmented } \\
\text { Neutrophil ( } \\
\left.10^{9} / \mathrm{L}\right)\end{array}$ & $\begin{array}{l}0.18 \pm \\
0.04^{\mathrm{a}}\end{array}$ & $0.11 \pm 0.02$ & $\begin{array}{l}0.11 \pm \\
0.02^{\mathrm{a}}\end{array}$ & $0.20 \pm 0.04^{\mathrm{a}}$ & $0.27 \pm 0.16^{a}$ & $0.31 \pm 0.04^{a}$ & $0.31 \pm 0.08^{\mathrm{a}}$ & $0.29 \pm 0.11^{\mathrm{a}}$ & $\begin{array}{l}3.06 \pm \\
0.15^{\mathrm{b}}\end{array}$ \\
\hline $\begin{array}{l}\text { Eosinophil }(\times \\
\left.10^{9} / \mathrm{L}\right)\end{array}$ & $\begin{array}{l}0.03 \pm \\
0.01^{\mathrm{a}}\end{array}$ & $0.31 \pm 0.17^{\mathrm{ab}}$ & $\begin{array}{l}0.27 \pm \\
0.11^{ \pm \mathrm{b}}\end{array}$ & $0.78 \pm 0.04^{b}$ & $0.33 \pm 0.21^{\mathrm{ab}}$ & $0.50 \pm 0.05^{\mathrm{ab}}$ & $0.49 \pm 0.03^{\mathrm{ab}}$ & $0.70 \pm 0.16^{b}$ & $\begin{array}{l}0.52 \pm \\
0.07^{\mathrm{ab}}\end{array}$ \\
\hline $\begin{array}{l}\text { Basophil }\left(\times 10^{9} /\right. \\
\text { L) }\end{array}$ & $\begin{array}{l}0.00 \pm \\
0.00^{\mathrm{a}}\end{array}$ & $0.05 \pm 0.02^{c}$ & $\begin{array}{l}0.06 \pm \\
0.01^{c}\end{array}$ & $0.01 \pm 0.01^{\mathrm{ab}}$ & $0.00 \pm 0.00^{\mathrm{a}}$ & $0.00 \pm 0.00^{\mathrm{a}}$ & $0.00 \pm 0.00^{\mathrm{a}}$ & $0.04 \pm 0.02^{b c}$ & $\begin{array}{l}0.00 \pm \\
0.00^{\mathrm{a}}\end{array}$ \\
\hline $\begin{array}{l}\text { Monocyte (x } \\
\left.10^{9} / \mathrm{L}\right)\end{array}$ & $\begin{array}{l}0.10 \pm \\
0.01^{a}\end{array}$ & $0.08 \pm 0.03^{\mathrm{a}}$ & $\begin{array}{l}0.44 \pm \\
0.11^{a}\end{array}$ & $0.12 \pm 0.04^{\mathrm{a}}$ & $0.11 \pm 0.05^{\mathrm{a}}$ & $0.20 \pm 0.05^{a}$ & $0.16 \pm 0.33^{a}$ & $0.17 \pm 0.03^{\mathrm{a}}$ & $\begin{array}{l}0.46 \pm \\
0.05^{a}\end{array}$ \\
\hline
\end{tabular}

$\bar{a}, b, a b, c, b c, c d, a b c, b c d$ Different superscripts indicate significant difference across the different blood pathogen infected cattle groups, $p<0.05$

evansi were successfully amplified using a PCR-based technique. Theileria species were the predominant species detected in 44 out of 61 cattle. The high detection rate of Theileria DNA (72.13\%) confirms that Theileria infection is endemic in a cattle farm in Pahang, with $T$. sinensis being the most commonly detected Theileria species. Molecular evidence of theileriosis being caused by $T$. sinensis and T. orientalis in Malaysia was first documented by Kho et al. [26] and Ola-Fadunsin et al. [59], respectively. However, the association between bovine anaemia and $T$. sinensis infection is presented for the first time in this study. $T$. sinensis is one of the major causative agents of bovine theileriosis in China, and it is transmitted by Haemaphysalis qinghaiensis ticks [32]. Therefore, its detection in Malaysian cattle suggests the possible introduction, importation, or close contact of an asymptomatic carrier cattle to naïve cattle in Malaysia. Consequently, T. sinensis is now indigenous to Malaysia and no longer restricted to China. In addition, the detection of $T$. sinensis in cattle ticks (Rhipicephalus microplus and Haemaphysalis bispinosa) found in Malaysia implies that these ticks potentially play 
Table 5 Serum biochemistry parameters of Kedah-Kelantan X Brahman cattle naturally infected by blood pathogens

\begin{tabular}{|c|c|c|c|c|c|c|c|c|c|}
\hline $\begin{array}{l}\text { Serum } \\
\text { biochemical } \\
\text { parameters }\end{array}$ & $\begin{array}{l}\text { T. evansi } \\
\text { infected } \\
\text { cattle } \\
(n=3)\end{array}$ & $\begin{array}{l}\text { Candidatus } \\
\text { M. } \\
\text { haemobos } \\
\text { infected } \\
\text { cattle } \\
(n=5)\end{array}$ & $\begin{array}{l}T . \\
\text { sinensis } \\
\text { infected } \\
\text { cattle } \\
(n=9)\end{array}$ & $\begin{array}{l}T . \\
\text { orientalis }+A . \\
\text { marginale } \\
\text { infected } \\
\text { cattle }(n=10)\end{array}$ & $\begin{array}{l}\text { A. } \\
\text { platys }+T . \\
\text { sinensis } \\
\text { infected } \\
\text { cattle } \\
(n=3)\end{array}$ & $\begin{array}{l}\text { T. sinensis + } \\
\text { C. M. } \\
\text { haemobos } \\
\text { infected } \\
\text { cattle } \\
(n=17)\end{array}$ & $\begin{array}{l}T . \\
\text { orientalis + } \\
T . \text { sinensis } \\
\text { infected } \\
\text { cattle } \\
(n=9)\end{array}$ & $\begin{array}{l}\text { C. } M . \\
\text { haemobos }+T . \\
\text { sinensis }+A . \\
\text { marginale } \\
\text { infected cattle } \\
(n=5)\end{array}$ & $\begin{array}{l}\text { Clinically } \\
\text { healthy } \\
\text { cattle } \\
(n=17)\end{array}$ \\
\hline ALP (U/L) & $\begin{array}{l}351.00 \pm \\
5.00^{d}\end{array}$ & $54.00 \pm 6.35^{\mathrm{ab}}$ & $\begin{array}{l}44.67 \pm \\
4.22^{\mathrm{a}}\end{array}$ & $57.50 \pm 6.97^{\mathrm{ab}}$ & $\begin{array}{l}51.00 \pm \\
5.14^{\mathrm{ab}}\end{array}$ & $82.35 \pm 5.53^{b c}$ & $\begin{array}{l}65.63 \pm \\
6.26^{\mathrm{ab}}\end{array}$ & $107.25 \pm 6.07^{c}$ & $\begin{array}{l}71.94 \pm \\
4.62^{\mathrm{bc}}\end{array}$ \\
\hline AST (U/L) & $\begin{array}{l}135.50 \pm \\
2.50^{\mathrm{a}}\end{array}$ & $57.50 \pm 5.92^{\mathrm{b}}$ & $\begin{array}{l}81.00 \pm \\
9.08^{b}\end{array}$ & $68.10 \pm 9.17^{b}$ & $\begin{array}{l}67.00 \pm \\
6.00^{\mathrm{b}}\end{array}$ & $70.13 \pm 5.53^{b}$ & $71.13 \pm 5.18^{b}$ & $62.40 \pm 7.69^{b}$ & $\begin{array}{l}78.86 \pm \\
2.48^{\mathrm{b}}\end{array}$ \\
\hline Y-GT (U/L) & $\begin{array}{l}58.00 \pm \\
1.00^{\mathrm{b}}\end{array}$ & $19.50 \pm 3.07^{\mathrm{a}}$ & $\begin{array}{l}17.11 \pm \\
2.90^{\mathrm{a}}\end{array}$ & $31.20 \pm 6.06^{a}$ & $25.50 \pm 6.50^{a}$ & $20.38 \pm 2.95^{\mathrm{a}}$ & $22.11 \pm 4.28^{\mathrm{a}}$ & $29.20 \pm 3.71^{a}$ & $\begin{array}{l}22.79 \pm \\
1.48^{\mathrm{a}}\end{array}$ \\
\hline $\begin{array}{l}\text { Total proteins } \\
\text { (g/L) }\end{array}$ & $\begin{array}{l}92.40 \pm \\
1.80^{\mathrm{c}}\end{array}$ & $76.93 \pm 4.05^{\mathrm{a}}$ & $\begin{array}{l}75.29 \pm \\
2.95^{\mathrm{ab}}\end{array}$ & $79.73 \pm 2.58^{b}$ & $\begin{array}{l}76.40 \pm \\
1.00^{\mathrm{ab}}\end{array}$ & $76.17 \pm 1.68^{\mathrm{ab}}$ & $78.06 \pm 2.80^{b}$ & $76.13 \pm 2.06^{\mathrm{ab}}$ & $\begin{array}{l}71.85 \pm \\
2.04^{\mathrm{ab}}\end{array}$ \\
\hline Albumin (g/L) & $\begin{array}{l}21.75 \pm \\
0.65^{\mathrm{a}}\end{array}$ & $27.95 \pm 1.35^{b}$ & $\begin{array}{l}30.46 \pm \\
0.99^{\mathrm{bc}}\end{array}$ & $31.52 \pm 0.80^{b c}$ & $\begin{array}{l}32.90 \pm \\
3.40^{\mathrm{bcd}}\end{array}$ & $32.62 \pm 0.82^{\mathrm{bcd}}$ & $\begin{array}{l}33.67 \pm \\
1.19^{\mathrm{cd}}\end{array}$ & $32.30 \pm 2.03^{b c}$ & $\begin{array}{l}37.29 \pm \\
0.75^{d}\end{array}$ \\
\hline Globulin (g/L) & $\begin{array}{l}70.65 \pm \\
1.15^{\mathrm{b}}\end{array}$ & $48.98 \pm 2.71^{\mathrm{a}}$ & $\begin{array}{l}44.83 \pm \\
2.57^{\mathrm{a}}\end{array}$ & $48.21 \pm 2.11^{\mathrm{a}}$ & $43.50 \pm 2.40^{\mathrm{a}}$ & $43.56 \pm 1.54^{\mathrm{a}}$ & $44.39 \pm 2.42^{\mathrm{a}}$ & $43.83 \pm 1.57^{\mathrm{a}}$ & $\begin{array}{l}37.84 \pm \\
1.03^{\mathrm{a}}\end{array}$ \\
\hline A: G (Unit) & $\begin{array}{l}0.31 \pm \\
0.01^{\mathrm{a}}\end{array}$ & $0.72 \pm 0.02^{b}$ & $\begin{array}{l}0.70 \pm \\
0.04^{b}\end{array}$ & $0.67 \pm 0.03^{b}$ & $0.84 \pm 0.14^{b c}$ & $0.75 \pm 0.21^{b}$ & $0.73 \pm 0.04^{b}$ & $0.76 \pm 0.07^{b}$ & $\begin{array}{l}1.01 \pm \\
0.03^{c}\end{array}$ \\
\hline $\begin{array}{l}\text { Total bilirubin } \\
(\mu \mathrm{mol} / \mathrm{L})\end{array}$ & $\begin{array}{l}30.30 \pm \\
0.50^{c}\end{array}$ & $5.05 \pm 0.93^{\mathrm{ab}}$ & $\begin{array}{l}9.27 \pm \\
1.57^{\mathrm{b}}\end{array}$ & $8.03 \pm 1.29^{\mathrm{ab}}$ & $5.30 \pm 0.01^{\mathrm{ab}}$ & $9.03 \pm 1.04^{b}$ & $7.37 \pm 0.81^{\mathrm{ab}}$ & $7.88 \pm 1.51^{\mathrm{ab}}$ & $\begin{array}{l}3.87 \pm \\
0.30^{\mathrm{a}}\end{array}$ \\
\hline $\begin{array}{l}\text { Conjugated } \\
\text { bilirubin } \\
\text { ( } \mu \mathrm{mol} / \mathrm{L})\end{array}$ & $\begin{array}{l}8.50 \pm \\
0.20^{\mathrm{b}}\end{array}$ & $2.23 \pm 0.44^{a}$ & $\begin{array}{l}3.58 \pm \\
0.54^{\mathrm{a}}\end{array}$ & $3.40 \pm 0.47^{\mathrm{a}}$ & $2.30 \pm 0.30^{\mathrm{a}}$ & $3.17 \pm 0.27^{\mathrm{a}}$ & $2.75 \pm 0.36^{a}$ & $3.18 \pm 0.51^{a}$ & $\begin{array}{l}2.17 \pm \\
0.13^{\mathrm{a}}\end{array}$ \\
\hline $\begin{array}{l}\text { Unconjugated } \\
\text { bilirubin } \\
\text { ( } \mu \mathrm{mol} / \mathrm{L})\end{array}$ & $\begin{array}{l}21.80 \pm \\
0.30^{\mathrm{e}}\end{array}$ & $2.83 \pm 0.53^{\mathrm{ab}}$ & $\begin{array}{l}5.69 \pm \\
1.05^{c d}\end{array}$ & $4.63 \pm 0.85^{b c d}$ & $\begin{array}{l}3.00 \pm \\
0.30^{\mathrm{abc}}\end{array}$ & $4.83 \pm 0.50^{b c d}$ & $\begin{array}{l}4.61 \pm \\
0.48^{\mathrm{bcd}}\end{array}$ & $4.70 \pm 1.03^{b c d}$ & $\begin{array}{l}1.41 \pm \\
0.21^{a}\end{array}$ \\
\hline $\begin{array}{l}\text { Sodium } \\
\text { (mmol/L) }\end{array}$ & $\begin{array}{l}191.50 \pm \\
6.50^{\mathrm{b}}\end{array}$ & $\begin{array}{l}209.00 \pm \\
6.06^{\mathrm{b}}\end{array}$ & $\begin{array}{l}187.22 \pm \\
7.22^{b}\end{array}$ & $187.56 \pm 6.20^{b}$ & $\begin{array}{l}168.50 \pm \\
7.19^{\mathrm{ab}}\end{array}$ & $180.78 \pm 8.72^{a b}$ & $\begin{array}{l}179.89 \pm \\
6.93^{\mathrm{ab}}\end{array}$ & $171.50 \pm 3.00^{\mathrm{ab}}$ & $\begin{array}{l}141.00 \pm \\
1.87^{\mathrm{a}}\end{array}$ \\
\hline $\begin{array}{l}\text { Potassium } \\
\text { (mmol/L) }\end{array}$ & $\begin{array}{l}6.15 \pm \\
0.05^{\mathrm{b}}\end{array}$ & $6.50 \pm 0.58^{b}$ & $\begin{array}{l}5.86 \pm \\
0.19^{\mathrm{ab}}\end{array}$ & $6.10 \pm 0.47^{b}$ & $5.20 \pm 1.20^{\mathrm{ab}}$ & $5.76 \pm 0.24^{\mathrm{ab}}$ & $5.57 \pm 0.29^{\mathrm{ab}}$ & $5.28 \pm 0.39^{\mathrm{ab}}$ & $\begin{array}{l}4.65 \pm \\
0.10\end{array}$ \\
\hline $\begin{array}{l}\text { Chloride } \\
\text { (mmol/L) }\end{array}$ & $\begin{array}{l}126.50 \pm \\
5.50^{\mathrm{ab}}\end{array}$ & $\begin{array}{l}150.50 \pm \\
4.45^{b}\end{array}$ & $\begin{array}{l}133.33 \pm \\
6.15^{\mathrm{ab}}\end{array}$ & $129.40 \pm 5.74^{\mathrm{ab}}$ & $\begin{array}{l}117.50 \pm \\
3.32^{\mathrm{a}}\end{array}$ & $126.72 \pm 6.70^{a b}$ & $\begin{array}{l}126.44 \pm \\
5.10^{\mathrm{ab}}\end{array}$ & $118.00 \pm 9.58^{a}$ & $\begin{array}{l}103.00 \pm \\
1.01^{\mathrm{a}}\end{array}$ \\
\hline $\begin{array}{l}\text { Inorganic } \\
\text { phosphate } \\
\text { (mmol/L) }\end{array}$ & $\begin{array}{l}2.75 \pm \\
0.05\end{array}$ & $2.35 \pm 0.40$ & $\begin{array}{l}2.38 \pm \\
0.17\end{array}$ & $2.54 \pm 0.12$ & $2.65 \pm 0.65$ & $2.82 \pm 0.15$ & $2.73 \pm 0.15$ & $2.68 \pm 0.27$ & $\begin{array}{l}2.10 \pm \\
0.07\end{array}$ \\
\hline $\begin{array}{l}\text { Creatinine } \\
(\mu \mathrm{mol} / \mathrm{L})\end{array}$ & $\begin{array}{l}182.00 \pm \\
1.00^{\mathrm{d}}\end{array}$ & $\begin{array}{l}104.75 \pm \\
6.87^{b}\end{array}$ & $\begin{array}{l}85.00 \pm \\
4.17^{\mathrm{a}}\end{array}$ & $104.30 \pm 3.60^{\mathrm{ab}}$ & $\begin{array}{l}95.00 \pm \\
2.00^{\mathrm{ab}}\end{array}$ & $113.59 \pm 3.25^{b}$ & $\begin{array}{l}104.57 \pm \\
4.11^{\mathrm{ab}}\end{array}$ & $112.75 \pm 4.25^{b}$ & $\begin{array}{l}136.74 \pm \\
3.17^{c}\end{array}$ \\
\hline Urea (mmol/L) & $\begin{array}{l}11.30 \pm \\
1.00^{\mathrm{d}}\end{array}$ & $6.88 \pm 1.11^{\mathrm{abc}}$ & $\begin{array}{l}6.11 \pm \\
0.51^{\mathrm{ab}}\end{array}$ & $7.24 \pm 0.54^{\mathrm{abc}}$ & $8.40 \pm 0.30^{c}$ & $7.94 \pm 0.26^{\mathrm{bc}}$ & $7.68 \pm 0.54^{b c}$ & $7.24 \pm 0.48^{\mathrm{abc}}$ & $\begin{array}{l}5.27 \pm \\
0.24^{\mathrm{a}}\end{array}$ \\
\hline
\end{tabular}

important roles in the transmission of theileriosis [26]. T. sinensis was also recently detected in Russian cattle, which further indicates that the pathogen is no longer indigenous to Asia [60]. Phylogenetic analyses of the Theileria, Anaplasma, C. Mycoplasma haemobos, and T. evansi Malaysian strains showed that they are tightly grouped together and closely related to their respective reference strains from different geographic regions. The sequence similarity among the Malaysian strains and those in other parts of the world might have been caused by the movement/importation of cattle carrying the blood pathogens into Southeast Asia. Astonishingly, previously reported T. evansi Malaysian strains [61] are different from the strains reported in this study. This, however, proves that some degree of polymorphism exists among $T$. evansi strains detected in the same herd or in endemic areas (reviewed in Ref [62]). Besides $A$. marginale, the detection of another Anaplasma species (A. platys) in Malaysian cattle agrees with the findings of Koh et al. [57], who detected other Anaplasma species such as A. capra, A. phagocytophilum, and Candidatus A. camelii in domestic and wild animals in Peninsular Malaysia. Anaplasma platys is a rickettsial bacteria transmitted by Rhipicephalus sanguineus sensu lato that infects a wide range of hosts such as humans, horses, small ruminants, and preferentially dogs [21, 22]. It 


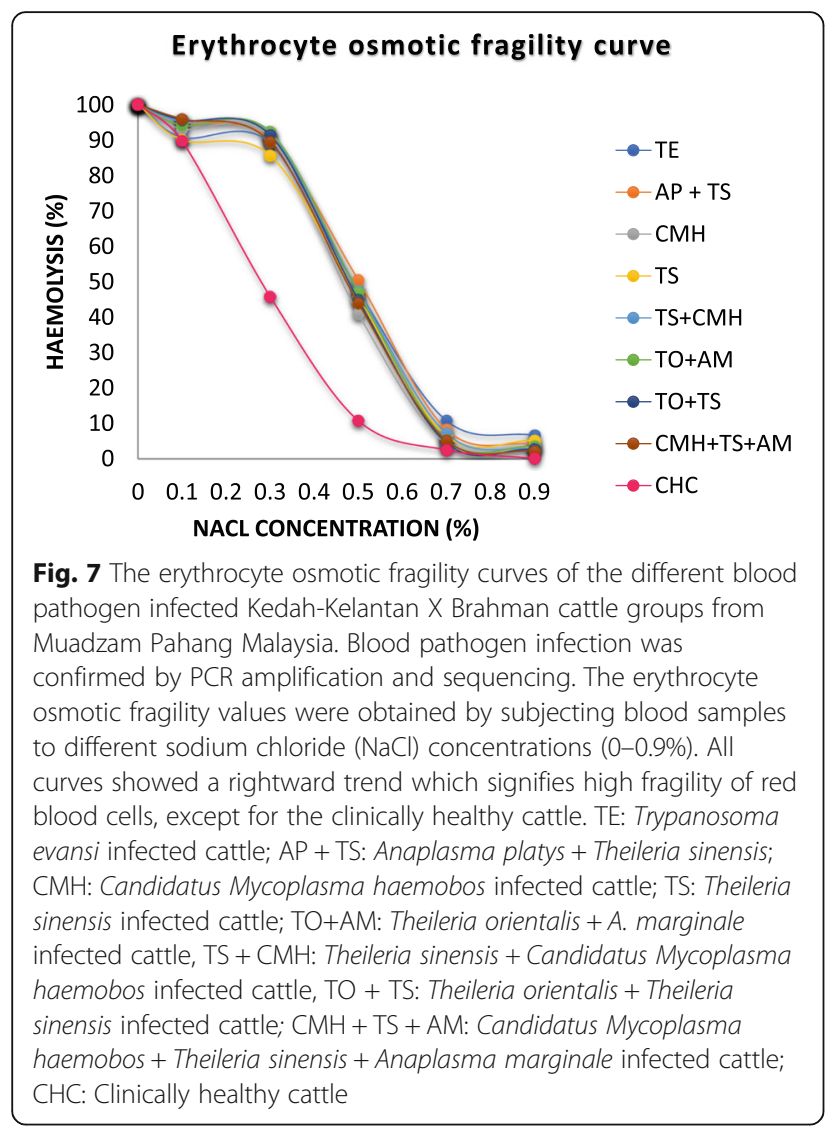

causes canine infectious cyclic thrombocytopenia, and its pathogenic role in humans, small ruminants, and horses is not fully understood but has been associated with chronic nonspecific clinical signs such as headaches and muscle pains in humans [63]. Humans in close contact with their pets usually become infected. Our discovery of $A$. platys in cattle agrees with the study by Chien et al. [23], which reported a similar finding for Vietnamese cattle. This pathogen has also been detected in cattle in Italy [64] and Nigeria [65]. The detection of A. platys in cattle raises an urgent concern about the zoonotic implication of this blood pathogen in Malaysia, as pastoralists, veterinarians, and para-veterinary personnel are at high risk of exposure. The high detection rates of blood pathogen co-infections recorded in this study is very common in cattle, and co-transmission of multiple pathogens enhances the disease severity and/or evolves with nonspecific clinical signs and symptoms, resulting in diagnostic complexities [66]. Co-infections with two to six different blood pathogens in cattle have been reported in Kenya [2], Malaysia [6], Russia [60], Uganda [67], Tanzania [68], and southwestern Ethiopia [69], and a majority of mixed infections usually occur as double infections $[60,69]$.

Significant changes in haemato-biochemical parameters were observed in the T. evansi-infected cattle group, $T$. sinensis-infected cattle group, and A. platys $+T$. sinensis-infected cattle group. Hemolytic anaemia in

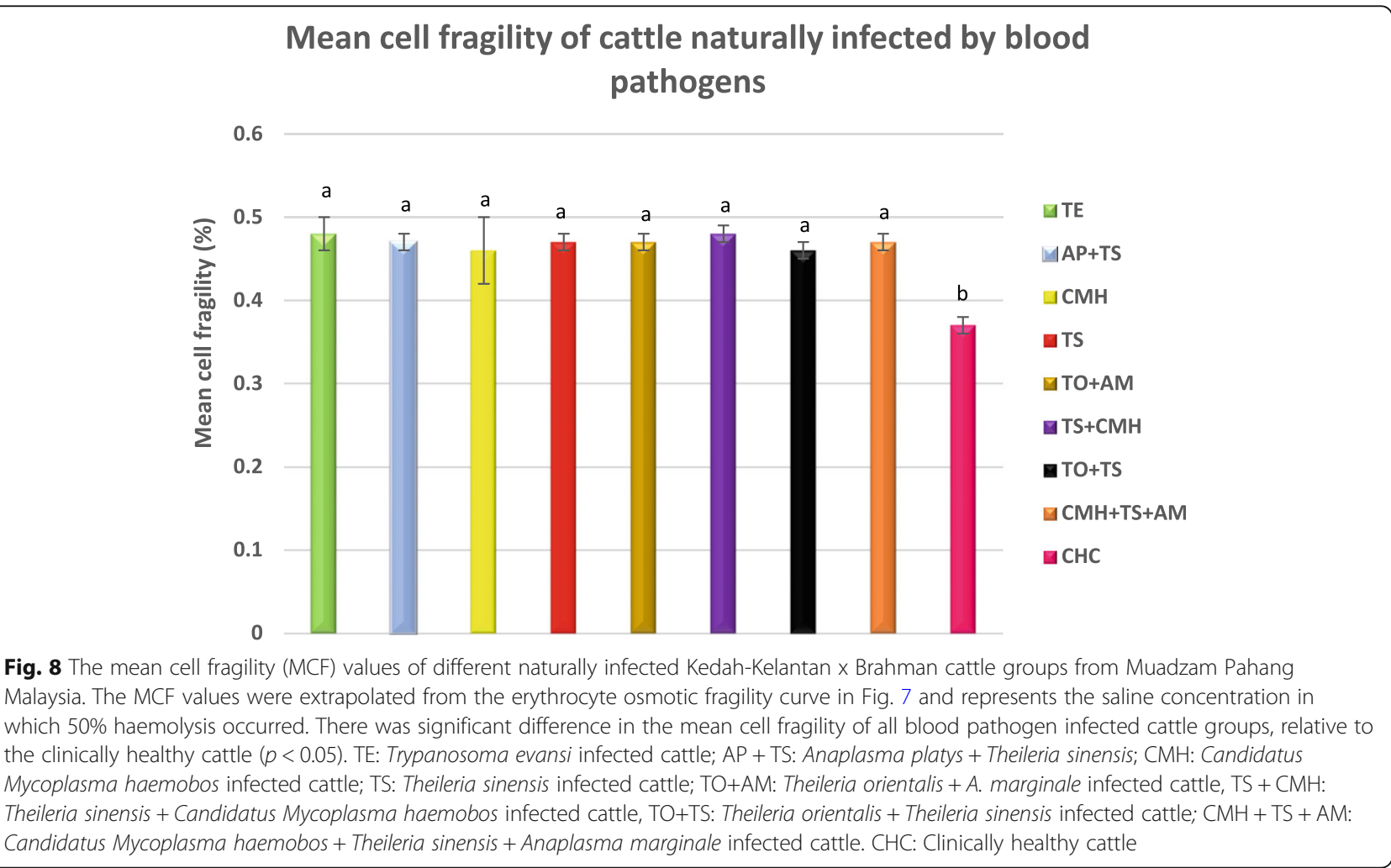


trypanosomosis is usually due to mechanical injury to the erythrocytes and to the subsequent lysis caused by the lashing action of Trypanosoma flagella and attachment of the trypanosomes onto red blood cell surfaces via sialic acid receptors [70]. The presence of spherocytes in the stained blood smears of T. evansi-infected cattle may be due to partial erythrophagocytosis of the autoantibodies and complement-coated erythrocytes [71]. Elevations in the serum total and unconjugated bilirubin in the T. evansi group were due to massive intravascular hemolysis with the increased release and breakdown of hemoglobin and the conversion to bilirubin by macrophages. Elevation of the liver enzyme activities in the $T$. evansi group was ascribed to cellular hypoxia and/or centrilobular necrosis due to a low liver blood volume, which leads to hepatocyte injury [72]. This hepatocellular injury could have contributed to the slow rate of bilirubin conjugation. Albumin is a negative acute phase protein that decreases in acute inflammatory conditions; therefore, the induction of inflammatory conditions by the trypanosomes could lead to hypoalbuminemia. The albumin-to-globulin ratio also decreased with an increase in inflammation. The toxic metabolites of the protozoa may have caused possible injury to the kidneys or renal insufficiency, hence the increased serum urea and creatinine levels in $T$. evansi-infected cattle [73]. In addition, prerenal dehydration could be responsible for the increase in serum urea and creatinine levels in T. evansi-infected cattle.

The cases of mild anaemia recorded in the T. sinensisinfected cattle group could be ascribed to extravascular hemolysis of abnormally shaped red blood cells performed by the mononuclear phagocyte system [74]. The finding of normocytic normochromic anaemia in bovine theileriosis agrees with the report of Ayadi et al. [34] for cattle reared in Algeria. The finding of a normal PCV value with a low red blood cell count and hemoglobin concentration in $A$. platys $+T$. sinensis is highly suggestive of the presence of large erythrocytes and a decrease in plasma volume due to dehydration, giving a false PCV value. Therefore, macrocytic normochromic anaemia reported in this cattle group is responsive because anisocytosis and macrocytic indices support the regenerative status in ruminants [75]. Degenerative left shift, hypernatremia, hyperkalemia, hypochloridemia, and hyperproteinemia with low albumin-to-globulin ratios were other hemato-biochemical features reported in A platys $+T$. sinensis double species co-infection, and these were suggestive of an ongoing inflammatory condition and dehydration. The triple infection cattle group (C. $M$. haemobos $+T$. sinensis $+A$. marginale) had normal hematological values, but the presence of a few spherocytes on the blood smear may indicate possible recovery from immune-mediated hemolytic anaemia (IMHA) associated with blood pathogen infections. Most cases of IMHA in cattle have been associated with secondary infectious diseases such as theileriosis and anaplasmosis $[76,77]$, and a correlation between infection and autoimmunity was described based on the hypothesis of 'molecular mimicry'. This mechanism suggests that there is an antigenic cross-reaction between pathogen-expressed epitopes, and self-molecules or autoantigens [78]. Animals infected with Anaplasma species produce antibodies against parasitized and non-parasitized erythrocytes [79]. Therefore, spherocytosis in IMHA usually occurs following partial phagocytosis of infected red blood cells in which altered cell membranes are coated with immunoglobulins (IgG and IgM) and complement $(\mathrm{C} 3 \mathrm{~b})$ produced to combat the blood pathogens [24].

Increased globulin concentration in the T. evansi-, $C$. $M$. haemobos-, and T. orientalis $+A$. marginale-infected cattle groups signifies the presence of a current inflammatory condition caused by the bacteria and protozoa or by secondary bacterial infections. This is in agreement with the study by Ashuma et al. [80], who reported an increase in circulating immunoglobulins in dairy cattle naturally infected with $A$. marginale. Degenerative left shift was one of the major hematological abnormalities observed in all of the infected cattle groups, and it is a sign of severe acute inflammatory response to the blood pathogens. In this study, a degenerative left sign signifies that the demand for neutrophils from an inflammatory focus is overwhelming and that the granulopoietic capacity was exceeded $[81,82]$. The functional storage compartment of mature neutrophils in the bone marrow of cattle is low when compared to other mammalian species [83], and in severe inflammatory conditions, increased demand for neutrophils rapidly exhausts the circulating and marrow storage pool. Subsequently, immature neutrophils such as the band, metamyelocytes, and myelocytes are released into peripheral circulation. Bacterial and protozoal infections tend to cause immunosuppression, which makes the host susceptible to secondary infections.

Natural infections of cattle with these blood pathogens increase the fragility of red blood cells. This suggests that, even when the blood pathogens are cleared or reduced from peripheral circulation, they 'leave behind' red blood cells that are susceptible to hypo-osmotic stress. It is physiologically expected that fewer RBCs should hemolyze at higher saline concentrations $(0.9 \%)$, but in this case, more RBCs were still hemolyzed at this concentration, suggesting that the RBC membrane was compromised by the effect of the blood pathogens. Additionally, the EOF curves exhibited a rightward shift, and this further confirmed the increased instability of the red blood cell membrane induced by blood pathogens [84]. 
In general, blood pathogens induce structural, biochemical, and functional damage to the erythrocyte membrane (degradation of the membrane polyunsaturated fatty acids) and make them vulnerable to reactive oxygen species and susceptible to hemolysis $[8,37]$.

Our finding of hypernatremia in all cattle groups was not in agreement with the findings of Somu et al. [87], who reported hyponatremia in Theileria-infected cattle. Therefore, we suggest that a decrease in serum sodium level may have been present but was probably masked by dehydration. Prerenal dehydration could be responsible for the hyperkalemia and hyperchloridemia observed in all cattle groups [88]. The Theileria orientalis, C. Mycoplasma haemobos, and Anaplasma marginale triple infections confirmed by PCR tests in the sampled cattle test were considered subclinical based on the absence of anaemia, on the absence of blood pathogens on thin blood smears, on the presence of blood pathogen DNA, and on the presence of nonspecific clinical symptoms such as anorexia and ocular discharge. Therefore, not determining the different stages of blood pathogen infection (low, moderate, or high) is a limitation of the current study. Another limitation of this study is the failure to document the body conditions of the sampled cattle.

\section{Conclusions}

Trypanosomosis, theileriosis due to $T$. sinensis and $A$. platys $+T$. sinensis mixed infections were observed to be the main causes of anaemia in 15 out of 61 (24.59\%) sampled cattle. Therefore, we present the first evidence of Theileria sinensis associated bovine anaemia (TSABA) in Malaysian beef cattle. Anisocytosis, poikilocytosis, mild spherocytosis, degenerative left shift, increased plasma protein, hyperkalaemia, hypernatraemia, hyperchloridaemia were significant findings in most of the blood pathogen infected cattle groups. All infected cattle had circulating erythrocytes that are very susceptible to hypo-osmotic stress. Discovery of Anaplasma platys based on 16S rRNA gene detection in cattle raises a considerable concern about possible zoonotic transmission of this pathogen in Malaysia. Future research endeavours may incorporate species-specific primers targeting $A$. platys to confirm its current status in the ruminant industry, and design natural control and prevention measures to mitigate this issue facing Malaysian livestock sector. Future studies that aim to better understand the vector linked to $A$. platys transmission in Malaysian cattle and risk of exposure of $A$. platys to local farmers, veterinary and para-veterinary personnel was also recommended. Additional investigations are needed to determine which tick species serve as the main vector of T. sinensis in Malaysia. Quantification of the pathogen gene copy numbers to determine the stage of infection is also recommend for future research involving natural blood pathogen infections in cattle.

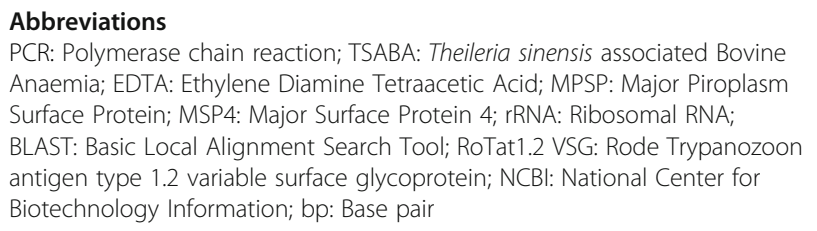
Anaemia; EDTA: Ethylene Diamine Tetraacetic Acid; MPSP: Major Piroplasm Surface Protein; MSP4: Major Surface Protein 4; rRNA: Ribosomal RNA; BLAST: Basic Local Alignment Search Tool; RoTat1.2 VSG: Rode Trypanozoon antigen type 1.2 variable surface glycoprotein; NCBI: National Center for Biotechnology Information; bp: Base pair

\section{Acknowledgements}

The authors would like to thank the staff at the Veterinary Haematology and Clinical Biochemistry Laboratory and Veterinary Parasitology Laboratory, Universiti Putra Malaysia for providing technical assistance.

\section{Authors' contributions}

Conception and study design: HH \& OA. Methodology: HH, OA, MRS, MA, MM, MZS, AS, DM, LC, FH \& AA. Data collection: OA, HH, MRS, MA, MM, AK, DM \& MZS. Data analysis \& Interpretation: OA \& HH. Intellectual

interpretation of the findings: HH \& OA. Manuscript draft and revision: OA \& $\mathrm{HH}$. All authors read and approved the final manuscript.

\section{Funding}

This work was funded by the Ministry of Education Malaysia (MOE) (FRGS/1/ 2019/WAB01/UPM/02/2) and IPS Research Grant, Universiti Putra Malaysia (GP-IPS/2018/9617000). PhD scholarship was provided by the Tertiary Education Trust Fund (TETFund) Nigeria (2016/2017AST\&D). The funding bodies did not play any role in the design of the study and collection, interpretation of data and in writing of the manuscript.

\section{Availability of data and materials}

DNA sequences obtained in this study have been submitted to GenBank database (accession number: MT184275-MT184279; MT271898 - MT271911; MT173810 - MT173814; MT259465 \& MT259466; MT514513-MT514514; MT521752 - MT521753). All data generated and analysed during the study are included in this published work.

\section{Declarations}

\section{Ethics approval and consent to participate}

This study was approved by the Universiti Putra Malaysia Animal Care and Use Committee and all guidelines for the use of animals were followed. AUP No. UPM/IACUC/AUP-R008/2020. The cattle farm owner consented to this study with a written consent form.

\section{Consent for publication}

Not applicable.

\section{Competing interests}

The authors have no competing interest in submission and publication of data in this article.

\section{Author details}

${ }^{1}$ Faculty of Veterinary Medicine, Universiti Putra Malaysia, UPM, 43400 Serdang, Selangor, Malaysia. ${ }^{2}$ Department of Veterinary Pathology and Microbiology, Faculty of Veterinary Medicine, University of Nigeria, Nsukka, Enugu State 410001, Nigeria. ${ }^{3}$ Animal Science Research Centre, Malaysian Agricultural Research and Development Institute, Headquarters, 43400 Serdang, Selangor, Malaysia. ${ }^{4}$ University Veterinary Hospital, Faculty of Veterinary Medicine, Universiti Putra Malaysia, UPM, 43400 Serdang, Selangor, Malaysia. ${ }^{5}$ Jabatan Perkhidmatan Veterinar, Pejabat KTS Zon Pahang Timur, 26700 Muadzam Shah, Pahang, Malaysia.

Received: 10 September 2020 Accepted: 12 May 2021

Published online: 18 July 2021

\section{References}

1. Tay ST, Koh FX, Kho KL, Ong BL. Molecular survey and sequence analysis of Anaplasma spp. in cattle and ticks in a Malaysian farm. Trop Biomed. 2014; 31(4):769-76. 
2. Adjou Moumouni PF, Aboge GO, Terkawi MA, Masatani T, Cao S, Kamyingkird $\mathrm{K}$, et al. Molecular detection and characterization of Babesia bovis, Babesia bigemina, Theileria species and Anaplasma marginale isolated from cattle in Kenya. Parasit Vectors. 2015;8(1):496. https://doi.org/1 0.1186/s13071-015-1106-9.

3. Mohd Hasan LI, Kho KL, Koh FX, Hassan Nizam QN, Tay ST. Molecular evidence of hemoplasmas in Malaysian cattle and ticks. Trop Biomed. 2017; 34(3):668-74.

4. Ereqat S, Nasereddin A, Al-Jawabreh A, Al-Jawabreh H, Al-Laham N, Abdeen Z. Prevalence of Trypanosoma evansi in livestock in Palestine. Parasit Vectors. 2020;13(1):1-8. https://doi.org/10.1186/s13071-020-3894-9.

5. Agina OA, Shaari MR, Isa NMM, Ajat M, Zamri-Saad M, Hamzah H. Clinical pathology, Immunopathology and Advanced Vaccine Technology in Bovine Theileriosis: A Review. Pathogens. 2020;9(9):697. https://doi.org/10.3390/pa thogens9090697.

6. Ola-Fadunsin SD, Maizatul AM, Ibrahim AR. Amlizawathy a, Chandrawathani $\mathrm{P}$, a JFF, et al. molecular prevalence and species co-infection of bovine Haemoparasites in peninsular Malaysia. Malays J Vet Res. 2017:8:13-22.

7. Hayashida K, Umemiya-Shirafuji R, Sivakumar T, Yamagishi J, Suzuki Y, Sugimoto C, et al. Establishment of a mouse-tick infestation model for Theileria orientalis and analysis of its transcriptome. Int J Parasitol. 2018;48:985-24.

8. Mijares A, Vivas J, Abad C, Betancourt M, Piñero S, Proverbio F, et al. Trypanosoma evansi: effect of experimental infection on the osmotic fragility, lipid peroxidation and calcium-ATPase activity of rat red blood cells. Exp Parasitol. 2010;124(3):301-5. https://doi.org/10.1016/j.exppara.2009.11.002.

9. Shebish E, Vemulapalli R, Oseto C. Prevalence and molecular detection of Anaplasma marginale, Babesia bovis and Babesia bigemina in cattle from Puntarenas Province, Costa Rica. Vet Parasitol. 2012;188(1-2):164-7. https:// doi.org/10.1016/j.vetpar.2012.03.009

10. Bilgiç HB, Karagenç $T$, Simuunza M, Shiels B, Tait A, Eren $H$, et al. Development of a multiplex PCR assay for simultaneous detection of Theileria annulata, Babesia bovis and Anaplasma marginale in cattle. Exp Parasitol. 2013;133(2):222-9. https://doi.org/10.1016/j.exppara.2012.11.005.

11. Li Y, Chen Z, Liu Z, Liu J, Yang J, Li Q, et al. Molecular identification of Theileria parasites of northwestern Chinese Cervidae. Parasit Vectors. 2014;7: $1-7$.

12. Cao S, Zhang S, Jia L, Xue S, Yu L, Kamyingkird K, et al. Molecular detection of Theileria species in sheep from northern China. J Vet Med Sci. 2013;75(9): 1227-30. https://doi.org/10.1292/jvms.13-0028.

13. Liu MM, Jia LJ, Cao SN, Adjou Moumouni PF, Jirapattharasate C, Wang GB, et al. Molecular detection of Theileria species in cattle from Jilin Province. China Trop Biomed. 2017;34:598-606.

14. Amer S, Ryu O, Tada C, Fukuda Y, Inoue N, Nakai Y. Molecular identification and phylogenetic analysis of Trypanosoma evansi from dromedary camels (Camelus dromedarius) in Egypt, a pilot study. Acta Trop. 2011;117(1):39-46. https://doi.org/10.1016/j.actatropica.2010.09.010.

15. Holland WG, My LN, Dung TV, Thanh NG, Tam PT, Vercruysse J. G. the influence of $T$. evansi infection on the immuno-responsiveness of experimentally infected water buffaloes. Vet Parasitol. 2001;102(3):225-34. https://doi.org/10.1016/50304-4017(01)00534-9.

16. Neimark H, Kocan KM. The cell wall-less rickettsia Eperythrozoon wenyonii is a mycoplasma. FEMS Microbiol Lett. 1997;156(2):287-91. https://doi.org/1 0.1111/j.1574-6968.1997.tb12742.x

17. Messick J. Hemotrophic mycoplasmas (hemoplasmas): a review and new insights into pathogenic potential. Vet Clin Pathol. 2004;33(1):2-13. https:// doi.org/10.1111/j.1939-165X.2004.tb00342.x.

18. Tagawa M, Matsumoto K, Inokuma H. Molecular detection of mycoplasma wenyonii and "Candidatus mycoplasma haemobos" in cattle in Hokkaido. Japan Vet Microbiol. 2008:132(1-2):177-80. https://doi.org/10.1016/j.vetmic.2008.05.006.

19. Palomar AM, Portillo A, Santibanez P, Mazuelas D, Roncero L, Garcia-Alvarez $L$, et al. Detection of tick-borne Anaplasma bovis, Anaplasma phagocytophilum and Anaplasma centrale in Spain. Med Vet Entomol. 2015; 29(3):349-53. https://doi.org/10.1111/mve.12124

20. Rjeibi MR, Ayadi O, Rekik M, Gharbi M. Molecular survey and genetic characterization of Anaplasma centrale, A . marginale and A . bovis in cattle from Algeria. Transbound Emerg Dis. 2017:1-9.

21. Dyachenko V, Pantchev N, Balzer HJ, Meyersen ASR. First case of Anaplasma platys infection in a dog from Croatia. Parasit Vectors. 2012;5(1):49. https:// doi.org/10.1186/1756-3305-5-49.

22. Kocan KM, De La Fuente J, Cabezas-Cruz A. The genus Anaplasma : new challenges after reclassification introduction and current and importance as pathogens antigenic diversity and epidemiology. Rev Sci Tech. 2015;34(2): 577-86. https://doi.org/10.20506/rst.34.2.2381.

23. Chien NTH, Nguyen TL, Bui KL, Van Nguyen T, Le TH. Anaplasma marginale and a. platys characterized from dairy and indigenous cattle and dogs in northern Vietnam. Korean J Parasitol. 2019;57(1):43-8. https://doi.org/10.3347/ kjp.2019.57.1.43.

24. Jalali SM, Ghorbanpour M, Jalali MR, Rasooli A, Safaie P, Norvej F, et al. Occurrence and potential causative factors of immune-mediated hemolytic anemia in cattle and river buffaloes. Vet Res Forum. 2018;9(1):7-12.

25. Hassan MA, Liu J, Rashid M, Iqbal N, Guan G, Yin H, et al. Molecular survey of piroplasm species from selected areas of China and Pakistan. Parasit Vectors. 2018;11:1-7.

26. Kho KL, Amarajothi ADG, Koh FX, Panchadcharam C, Hassan Nizam QN, Tay ST. The first molecular survey of theileriosis in Malaysian cattle, sheep and goats. Vet Parasitol Reg Stud Reports. 2017:10:149-53. https://doi.org/10.101 6/j.vprsr.2017.08.003

27. Sugimoto C, Fujisaki K. Non-transforming Theileria parasites of ruminants. In: Dobbelaere D, McKeever D, editors. Theileria (world class parasites): volume 3. Boston, London: Kluwer Academic Publishers; 2002. p. 93-106.

28. Gebrekidan H, Gasser RB, Baneth G, Yasur-Landau D, Nachum-Biala Y, Hailu $A$, et al. Molecular characterization of Theileria orientalis from cattle in Ethiopia. Ticks Tick Borne Dis. 2016;7(5):742-7. https://doi.org/10.1016/j. ttbdis.2016.03.005.

29. Park J, Han Y, Han D, Chae J, Chae J, Yu D, et al. Genetic characterization of Theileria orientalis from cattle in the Republic of Korea. Parasitol Res. 2017. 449-54. https://doi.org/10.1007/s00436-016-5316-7.

30. Mans BJ, Pienaar R, Latif AA. A review of Theileria diagnostics and epidemiology. Int J Parasitol Parasites Wildl. 2015;4(1):104-18. https://doi. org/10.1016/j.jppaw.2014.12.006.

31. Hayashida K, Kajino K, Hattori M, Wallace M, Morrison I, Greene MI, et al. MDM2 regulates a novel form of incomplete neoplastic transformation of Theileria parva infected lymphocytes. Exp Mol Pathol. 2013;94(1):228-38. https://doi.org/10.1016/j.yexmp.2012.08.008

32. Bai Q, Liu G, Yin H, Zhao Q, Liu D, Ren J, et al. Theileria sinensis sp nov: a new species of bovine Theileria-molecular taxonomic studies. Xu Mu Shou Yi Xue Bao. 2002:33:185-90.

33. Roland $L$, Drillich $M$, Iwersen $M$. Hematology as a diagnostic tool in bovine medicine. J Vet Diagn Investig. 2014;26(5):592-8. https://doi.org/10.1177/104063 8714546490 .

34. Ayadi O, Gharbi M, Benchikh-Elfegoun MC. Haematological and biochemical indicators of tropical theileriosis diseased cattle in wilaya of Sétif (north East Algeria). J Parasit Dis. 2017;41(2):538-42. https://doi.org/10.1007/s12639-0160846-6.

35. George N, Bhandari V, Reddy DPSP. Emergence of new genotype and diversity of Theileria orientalis parasites from bovines in India. Infect Genet Evol. 2015;36:27-34. https://doi.org/10.1016/j.meegid.2015.08.033.

36. Khan IA, Khan A, Hussain A, Raiz A, Aziz A. Hemato-biochemical alterations in cross bred cattle affected with bovine theileriosis in semi arid zone. Pak Vet J. 2011:31:137-40.

37. Igbokwe NA, Ojo NA, Igbokwe IO. Effects of sex and age on the osmotic stability of Sahel goat erythrocytes. Comp Clin Pathol. 2016;25(1):15-22. https://doi.org/10.1007/s00580-015-2130-z.

38. Faulkner WR, King JW. Manual of clinical laboratory procedures. Cleaveland: Chemical Rubber Company; 1970

39. Igbokwe NA, Igbokwe IO. Influence of extracellular media's ionic strength on the osmotic stability of Sahel goat erythrocytes. J Basic Clin Physiol Pharmacol. 2015;26:171-9.

40. Inaba M, Messick J. Erythrocyte membrane defects. In: Weiss DJ, Wardrop KJ Schalm OW, editors. Schalm's veterinary hematology. Ames: Wiley-Blackwell; 2010. p. 187-95

41. Kobo PI, Ayo JO, Aluwong T, Zezi AU, Maikai V, Ambali SF. Flavonoid mixture ameliorates increase in erythrocyte osmotic fragility and malondialdehyde concentration induced by Trypanosoma brucei bruceiinfection in Wistar rats. Res Vet Sci. 2014:96(1):139-42. https://doi.org/10.101 6/j.rvsc.2013.10.005.

42. Pati S, Panda SK, Behera PC, Panda MR. Assessment of erythrocyte osmotic fragility in cattle due to haemoprotozoan diseases. Int J Sci Environ Technol. 2017:6:1560-8

43. Oladele SB, Ayo J, Ogundipe S, Esievo K. Seasonal and species variations in erythrocytes osmotic fragility of indigenous poultry species in Zaria, northern Guinea Savannah zone of Nigeria. Poult Sci. 2003;56:1842-6. 
44. Ambali SF, Ayo JO, Ojo SA, Esievo KA. Ameliorative effect of vitamin C on chronic chlorpyrifos-induced erythrocyte osmotic fragility in Wistar rats. Hum Exp Toxicol. 2011;30(1):19-24. https://doi.org/10.1177/09603271103 68415.

45. Fazio F, Casella S, Giannetto C, Giudice E, Piccione G. Erythrocyte osmotic fragility in response to a short road transport in cattle, horses, and goats. $J$ Vet Behav Clin Appl Res. 2016;12:82-4. https://doi.org/10.1016/j.jveb.2015.11. 003.

46. Ariff OM, Sharifah NY, Hafidz AW. Status of beef industry of Malaysia. Malays Soc Anim Prod. 2015;18:1-21.

47. Oyewale JO. Effects of temperature and $\mathrm{pH}$ on osmotic fragility of erythrocytes of the domestic fowl (Gallus domesticus) and Guinea-fowl (Numida meleagris). Res Vet Sci. 1992;52(1):1-4. https://doi.org/10.1016/ 0034-5288(92)90049-8.

48. Parola P, Roux V, Camicas JL, Baradji I, Brouqui P, Raoult D. Detection of ehrlichiae in African ticks by polymerase chain reaction. Trans R Soc Trop Med Hyg. 2000;94(6):707-8. https://doi.org/10.1016/S0035-9203(00)90243-8.

49. Sogin ML. In: Innis MA, Gelfand DH, Sninsky JJ, White TJ, editors. PCR protocols: a guide to methods and applications. New York: Academic Press; 1990. p. 307-14

50. Su QL, Song HQ, Lin RQ, Yuan ZG, Yang JF, Zhao GH, et al. The detection of "Candidatus mycoplasma haemobos" in cattle and buffalo in China. Trop Anim Health Prod. 2010;42(8):1805-8. https://doi.org/10.1007/s11250-0109640-0.

51. Shkap V, Leibovitz B, Krigel Y, Molad T, Fish L, Mazuz M, et al. Concomitant infection of cattle with the vaccine strain Anaplasma marginale ss Centrale and field strains of a. marginale. Vet Microbiol. 2008;130(3-4):277-84. https:// doi.org/10.1016/j.vetmic.2008.02.013.

52. Ota N, Mizuno D, Kuboki N, Igarashi I, Nakamura Y, Yamashina H, et al. Epidemiological survey of Theileria orientalis infection in grazing cattle in the eastern part of Hokkaido, Japan. J Vet Med Sci. 2009;71(7):937-44. https://doi.org/10.1292/jvms.71.937.

53. Liu A, Guan G, Liu Z, Liu J, Leblanc N, Li Y, et al. Experimental parasitology detecting and differentiating Theileria sergenti and Theileria sinensis in cattle and yaks by PCR based on major piroplasm surface protein ( MPSP). Exp Parasitol. 2010;126(4):476-81. https://doi.org/10.1016/j.exppara.2010.05. 024.

54. Urakawa T, Claes F, Radwanska M, Majiwa PAO, Goddeeris $B$, Büscher $P$. Variable surface glycoprotein RoTat 1.2 PCR as a specific diagnostic tool for the detection of Trypanosoma evansi infections. Kinetoplastid Biol Dis. 2004; 3:1-6.

55. Kumar S, Stecher G, Li M, Knyaz C, Tamura K, MEGA X. Molecular evolutionary genetics analysis across computing platforms. Mol Biol Evol. 2018;35(6):1547-9. https://doi.org/10.1093/molbev/msy096.

56. Nei M, Kumar S. Molecular evolution and Phylogenetics. New York: Oxford University Press; 2000.

57. Koh FX, Panchadcharam C, Sitam FT, Tay ST. Molecular investigation of Anaplasma spp. in domestic and wildlife animals in Peninsular Malaysia. Vet Parasitol Reg Stud Rep. 2018;13:141-7. https://doi.org/10.1016/j.vprsr.2018. 05.006.

58. Duarte DP, Ferreira ÉR, Lima FM, Batista F, De Groote M, Horjales E, et al. Molecular characterization of Trypanosoma evansi mevalonate kinase (TeMVK). Front Cell Infect Microbiol. 2018;8:1-9. https://doi.org/10.3389/ fcimb.2018.00223.

59. Ola-Fadunsin SD, Sharma RSK, Abdullah DA, Gimba FI, Jesse FFA, Sani RA. Molecular detection, prevalence and risk factors of Theileria orientalis infection among cattle in Peninsular Malaysia. Prev Vet Med. 2020;180: 105027. https://doi.org/10.1016/j.prevetmed.2020.105027.

60. Bursakov SA, Kovalchuk SN. Co-infection with tick-borne disease agents in cattle in Russia. Ticks Tick Borne Dis. 2019;10(3):709-13. https://doi.org/10.1 016/j.ttbdis.2019.03.004.

61. ElShafie El, Sani RA, Hassan L, Sharma R, Bashir A, Abubakar IA. Active infection and morphometric study of Trypanosoma evansi among horses in peninsula Malaysia. Trop Biomed. 2013;30(3):444-50.

62. Desquesnes M, Holzmuller P, Lai D-H, Dargantes A, Lun Z-R, Jittaplapong S. Trypanosoma evansi and Surra: A Review and Perspectives on Origin, History, Distribution, Taxonomy, Morphology, Hosts, and Pathogenic Effects. Biomed Res Int. 2013:1-22. https://doi.org/10.1155/2013/194176.

63. Arraga-Alvarado CM, Qurollo BA, Parra OC, Berrueta MA, Hegarty BC, Breitschwerdt EB. Case report: molecular evidence of anaplasma platys infection in two women from Venezuela. Am J Trop Med Hyg. 2014;91(6): 1161-5. https://doi.org/10.4269/ajtmh.14-0372.

64. Zobba R, Anfossi AG, Parpaglia MLP, Dore GM, Chessa B, Spezzigu A, et al. Molecular investigation and phylogeny of anaplasma spp. in mediterranean ruminants reveal the presence of neutrophil-tropic strains closely related to a. platys. Appl Environ Microbiol. 2014;80(1):271-80. https://doi.org/10.112 8/AEM.03129-13.

65. Lorusso V, Wijnveld M, Majekodunmi AO, Dongkum C, Fajinmi A, Dogo AG, et al. Tick-borne pathogens of zoonotic and veterinary importance in Nigerian cattle. Parasit Vectors. 2016;9(1):1-13. https://doi.org/10.1186/s13 071-016-1504-7.

66. Karim S, Budachetri K, Mukherjee N, Williams J, Kausar A, Hassan MJ, et al. A study of ticks and tick-borne livestock pathogens in Pakistan. PLoS Negl Trop Dis. 2017;11(6):e0005681. https://doi.org/10.1371/journal.pntd.0005681.

67. Tayebwa DS, Vudriko P, Tuvshintulga B, Guswanto A, Nugraha AB, Gantuya $\mathrm{S}$, et al. Molecular epidemiology of Babesia species, Theileria parva, and Anaplasma marginale infecting cattle and the tick control malpractices in central and eastern Uganda. Ticks Tick Borne Dis. 2018;9(6):1475-83. https:// doi.org/10.1016/j.ttbdis.2018.06.012.

68. Ringo AE, Aboge GO, Adjou Moumouni PF, Hun Lee S, Jirapattharasate C, Liu M, et al. Molecular detection and genetic characterisation of pathogenic Theileria, Anaplasma and Ehrlichia species among apparently healthy sheep in central and western Kenya. Onderstepoort J Vet Res. 2019;86(1):1-8. https://doi.org/10.4102/ojvr.v86i1.1630.

69. Hailemariam Z, Krücken J, Baumann M, Ahmed JS, Clausen P-H, Nijhof AM. Molecular detection of tick-borne pathogens in cattle from southwestern Ethiopia. PLoS One. 2017;12(11):e0188248. https://doi.org/10.1371/journal. pone.0188248.

70. Shehu SA, Ibrahim NDG, Esievo KAN, Mohammed G. Role of erythrocyte surface sialic acid inducing anaemia in Savannah Brown bucks experimentally infected with Trypanosoma Evans. Veterenarski Arh. 2006;26: $521-30$

71. Mbaya A, Kumshe H, Okwudiri C. The mechanisms of Anaemia in Trypanosomosis: a review. In: Silverberg DS, editor. Anemia. Rijeka: InTech; 2012. p. 269-82. https://doi.org/10.5772/29530.

72. Stockham SL. And Scott MA. Fundamentals of veterinary clinical pathology. 2nd ed. lowa: Blackwell Publishing; 2008.

73. Jain S, Gautam V, Naseem S. Acute-phase proteins: as diagnostic tool. J Pharm Bioallied Sci. 2011;3(1):118-27. https://doi.org/10.4103/0975-7406.764 89.

74. Singh A, Singh J, Grewal ASBR. Studies on some blood parameters of crossbred calves with experimental Theileria annulata infection. Vet Res Commun. 2001;25(4):289-300. https://doi.org/10.1023/A:1010678625336.

75. Grimes CN, Fry MM. Nonregenerative Anemia: mechanisms of decreased or ineffective erythropoiesis. Vet Pathol. 2015;52(2):298-311. https://doi.org/1 $0.1177 / 0300985814529315$

76. Seino K. Immune-mediated anemias in ruminants and horses. In: Weiss D, Wardrop K, editors. Schalm's veterinary hematology. 6th ed. Ames: WileyBlackwell; 2010. p. 233-8.

77. Carlson G. Diseases associated with increased erythrocyte destruction (hemolytic anemia). In: Smith B, editor. Large animal internal medicine. 4th ed. St. Louis: Mosby Elsevier; 2009. p. 1154-69.

78. Nassiri SM, Darvishi S, Khazraiinia P. Bovine immune-mediated hemolytic anemia: 13 cases (November 2008-august 2009). Vet Clin Pathol. 2011;40(4): 459-66. https://doi.org/10.1111/j.1939-165X.2011.00354.x.

79. Ashuma SA, Das SL, Kaur P, Bal MS, Batth BK, et al. Prevalence and haematobiochemical profile of Anaplasma marginale infection in dairy animals of Punjab (India). Asian Pac J Trop Med. 2013;6:139-44. https://doi.org/10.1016/ S1995-7645(13)60010-3.

80. Webb JL, KS L, Brockus CW. Duncan and Prasse's veterinary laboratory medicine: clinical pathology. In: Latimer KS, editor. Duncan and Prasse's veterinary laboratory medicine: clinical pathology. 5th ed. Chichester: Wiley; 2011. p. 3-44.

81. Burton $A G$, Harris LA, Owens SD, Jandrey KE. The prognostic utility of degenerative left shifts in dogs. J Vet Intern Med. 2013;27(6):1517-22. https://doi.org/10.1111/jvim.12208.

82. Antwi-Baffour S, Quao E, Kyeremeh R, Mahmood SA. Prolong Storage of Blood in EDTA Has an Effect on the Morphology and Osmotic Fragility of Erythrocytes. Int J Biomed Sci Eng. 2013;1:20. https://doi.org/10.11648/j. ijbse.20130102.11. 
83. Somu Y, Mani S, Muthusamy R, Mani S, Thangamani A, Konappan J, et al. Haemato- Biochemical and Electrolyte Alterations in Naturally Occurring Theileria Associated Bovine Anaemia (Taba). J Anim Heal Prod. 2017;5:64-7. https://doi.org/10.17582/journal.jahp/2017/5.2.64.67.

84. Takeet Ml, Adeleye Al, Adebayo OO, Akande FA. Haematology and serum biochemical alteration in stress induced equine theileriosis. A case report. Sci World J. 2009;4:19-21.

\section{Publisher's Note}

Springer Nature remains neutral with regard to jurisdictional claims in published maps and institutional affiliations.

Ready to submit your research? Choose BMC and benefit from:

- fast, convenient online submission

- thorough peer review by experienced researchers in your field

- rapid publication on acceptance

- support for research data, including large and complex data types

- gold Open Access which fosters wider collaboration and increased citations

- maximum visibility for your research: over $100 \mathrm{M}$ website views per year

At $\mathrm{BMC}$, research is always in progress.

Learn more biomedcentral.com/submissions 